\title{
Working
}

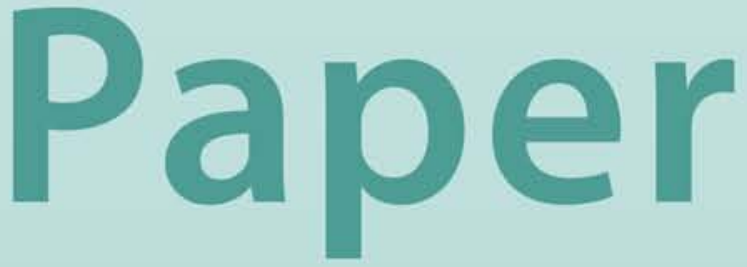


Capital Account Liberalization, Capital Flow Patterns, and Policy Responses in the EU's New Member States

Zsófia Árvai 


\title{
IMF Working Paper
}

European Department

\section{Capital Account Liberalization, Capital Flow Patterns, and Policy Responses in the EU's New Member States}

Prepared by Zsófia Árvai ${ }^{1}$

\begin{abstract}
Authorized for distribution by Emmanuel van der Mensbrugghe
\end{abstract}
November 2005

\begin{abstract}
This Working Paper should not be reported as representing the views of the IMF. The views expressed in this Working Paper are those of the author(s) and do not necessarily represent those of the IMF or IMF policy. Working Papers describe research in progress by the author(s) and are published to elicit comments and to further debate.

This paper discusses the experience of the EU's eight new member countries (EU8) between 1995 and 2003 when the bulk of capital account liberalization took place, focusing on interest-rate-sensitive portfolio flows and financial flows. It takes stock of the lessons from capital flow patterns to draw policy conclusions. There were two distinct groups in terms of the speed of capital account liberalization: rapid liberalizers and cautious liberalizers. The speed of disinflation and the level of public debt were major determinants of the size of interest-rate-sensitive portfolio inflows. Monetary and exchange rate policies were the main instruments used to react to large interest-sensitive inflows, whereas fiscal tightening was seldom used as a direct reaction to inflows.
\end{abstract}

JEL Classification Numbers: E44, F21, F32, F36

Keywords: EU accession, capital flows, capital account liberalization Author(s) E-Mail Address: zarvai@imf.org

\footnotetext{
${ }^{1}$ The author would like to thank Emmanuel van der Mensbrugghe and Nikolay Gueorguiev for helpful comments and Thomas Walter for editorial comments.
} 


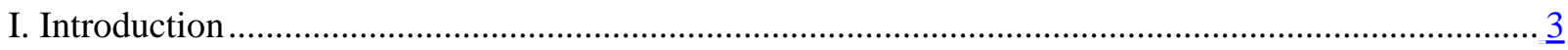

II. Capital Flows to Transition Economies: A Brief Survey of the Literature ...................................... $\underline{5}$

III. Differences and Similarities of Capital Account Liberalization in the EU8 .................................. 7

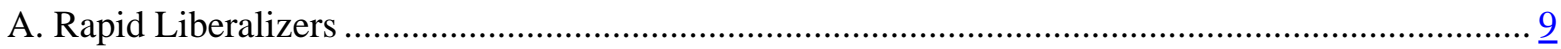

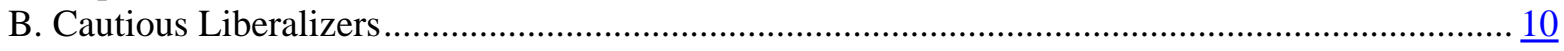

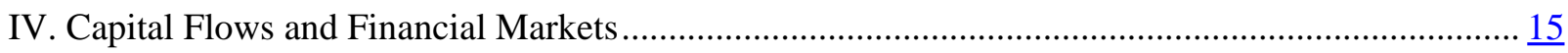

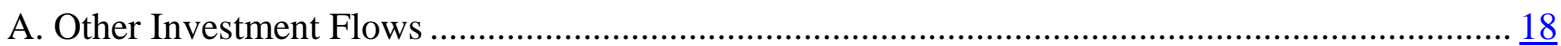

B. Portfolio Flows ............................................................................................................ 21

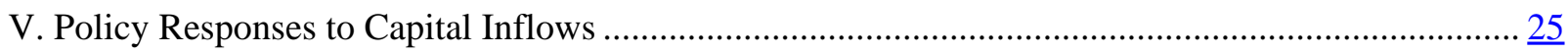

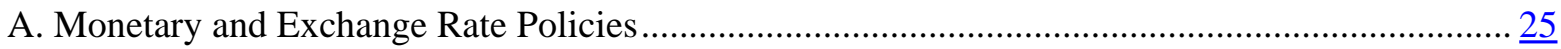

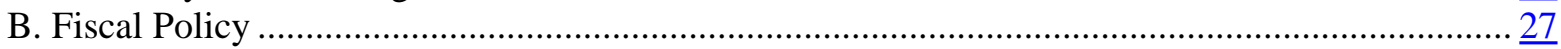

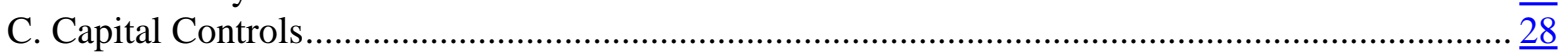

D. Debt Management ........................................................................................................ 28

E. Other Policy Responses .................................................................................................

VI. Policy Implications for Other Countries …........................................................................... 29

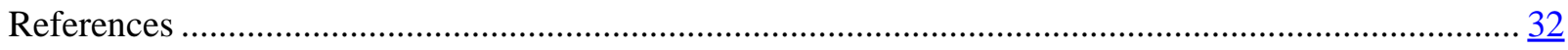

\section{Tables}

1. EU8 Countries: Breakdown of Net Capital Inflows into EU8 Countries, 1995-2003........................... 15

2. EU8 Countries: Size of the Government Securities Market, 1997-2004......................................... 22

3. Selected EU8 Countries: Government Balance - Countries with Prudent Fiscal Policies, 1995-2003...27

4. Selected EU8 Countries: Government Balance - Countries with Loose Fiscal Policies, 1995-2003..... $\underline{28}$

Figures

1. EU8 Countries: Net Capital Flows, 1995-2003....................................................................... 16

2. EU8 Countries: Other Investment Flows, 1995-2003............................................................... $\frac{20}{23}$

3. EU8 Countries: Interest Rate Differentials, 1995-2004................................................................ 23

Appendix Tables

1. Selected EU8 Countries: Nonresident Holdings of Government Securities, 1997-2004...................... 39

2. EU8 Countries: Real GDP Growth and the Current Account Balance, 1995-2003.............................. 40

Appendix Figures

A1. Selected EU8 Countries: Public Debt.....................................................................................

A2. EU8 Countries: End-of-Period CPI Inflation, 1995-2004......................................................... $\frac{36}{37}$

A3. Selected EU8 Countries: Monetary Policy and Exchange Rate Reactions.................................... $\underline{37}$ 


\section{INTRODUCTION}

The European Union's (EU's) new transition member countries (the Czech Republic, Estonia, Hungary, Latvia, Lithuania, Poland, the Slovak Republic, and Slovenia-the EU8) followed a

diverse path of capital account liberalization. ${ }^{2}$ The process had a common anchor-EU membership - which required full liberalization by the time of accession, and it was aided by OECD (Organization for Economic Cooperation and Development) accession for the Czech Republic, Hungary, Poland, and the Slovak Republic.

This paper discusses the experience of the EU8 countries between 1995 and 2003 when the bulk of capital account liberalization took place. ${ }^{3}$ It aims to take stock of the lessons from capital flow patterns and policy responses during the capital account liberalization process to draw policy implications for other emerging economies. The paper focuses on interest-ratesensitive portfolio flows, which can be highly volatile, and on financial credit flows, as these two types of flows posed more difficulties to monetary authorities in terms of economic policy, external vulnerability, and financial stability than foreign direct investment flows (FDI) did. ${ }^{4}$ Inflows are of particular interest in the case of the EU8 countries, as these flows complicated monetary and exchange rate policies more than the outflows which only infrequently interrupted the progress of these countries towards EU accession.

The main findings and policy implications can be summarized as follows:

- $\quad$ There are two distinct groups in terms of the speed of capital account liberalization: the Baltic countries and the Czech Republic liberalized their capital accounts relatively quickly, and most transactions were already unrestricted by 1995, whereas Hungary, Poland, the Slovak Republic, and Slovenia took a more cautious attitude and opened up their capital accounts only gradually, achieving full liberalization in 2001-04.

- $\quad$ In terms of the sequencing of the liberalization process, EU8 countries tended to liberalize FDI before financial flows, inflows before outflows, and long-term flows before short-term flows.

\footnotetext{
${ }^{2}$ The EU8 countries joined the European Union on May 1, 2004, together with Cyprus and Malta.

${ }^{3}$ Although the paper focuses on the 1995-2003 period, the transition from command to market economies started earlier, at the beginning of the 1990s. Throughout the paper, the term "transition period" refers to this extended period between the early 1990s and 2003.

${ }^{4}$ Interest-rate-sensitive flows refer to portfolio flows throughout the paper, even though some other forms of flows (e.g., bank deposits or trade credits) can also be motivated by the interest rate differential. However, the sensitivity of these others flows to changes in interest rates is much lower than that of portfolio flows, and their volatility related to interest rate movements is lower. These types of flows had less bearing on interest and exchange rate policy than portfolio flows did.
} 
- $\quad$ Foreign direct borrowing by enterprises was an important inflow channel in many countries in the 1990s due to the incomplete process of bank restructuring and privatization, as well as the easy access to foreign banks by foreign-owned enterprises. However, financial flows through the banking system became dominant from 2000 onward in almost all countries with the completion of bank restructuring and increasing competition for market share in retail banking.

- $\quad$ Cautious liberalizers received larger portfolio inflows than rapid liberalizers. Some cautious liberalizers - especially Hungary and Poland-were more vulnerable to inflows because they experienced a prolonged period of large interest differentials and had more financial assets to invest in, while the effectiveness of remaining capital controls eroded over time.

- $\quad$ The narrowing of the interest rate differential with disinflation and the level of public debt were the major determinants of the size of interest-rate-sensitive portfolio inflows.

- $\quad$ Opening up the government securities market to nonresident investors was a decisive step in the process of capital account liberalization, as this market proved to be the major channel for interest-rate-sensitive inflows in countries with developed financial markets.

- $\quad$ Monetary and exchange rate policies were the main instruments used to counteract excessive interest-rate-sensitive inflows, whereas fiscal tightening was seldom used as a direct reaction to inflows. The lack of fiscal consolidation contributed to slow disinflation and persistent inflows in some countries. Debt-management and bank regulation options were also used in several countries, while capital controls as a reaction to inflows were introduced only in Slovenia.

- $\quad$ Prospective capital account liberalizers should strive for relatively fast and sustainable disinflation to eliminate the interest rate differential while aiming to minimize risks to the current account, financial stability, and economic growth. Achieving this objective requires highly coordinated and disciplined economic policies with a more dominant role for fiscal policy in managing domestic demand than was observed in most EU8 countries.

The paper is structured as follows. Section II presents a brief literature survey focusing on transition economies. Section III discusses the differences and similarities of the various capital account liberalization schedules in the EU8 countries, and the requirements facing the authorities. Section IV analyzes broad capital flow patterns, and Section V discusses the policy responses to the inflows. Section VI draws conclusions for countries whose capital account liberalization still lies ahead. 


\section{Capital Flows to Transition Economies: A Brief Survey of the Literature}

The literature on capital account liberalization and capital flows is vast. One branch is aimed at testing the relationship between capital account liberalization and economic growth, but no consensus has emerged from the studies. On one end, Rodrik (1998) finds no correlation between capital account liberalization and growth, whereas on the other, Edwards (2001) finds that capital account liberalization has a strong positive effect, though this finding is mainly limited to high-income countries. Arteta, Eichengreen and Wyplosz (2001) come to the tentative conclusion that capital account liberalization has positive effects on growth only in countries that have already opened up more generally; thus the sequencing of reforms has important implications for the effects of capital account liberalization. This section gives a brief overview of some of the more recent literature on capital account liberalization and capital flows in transition economies.

Capital flows to transition economies are extensively documented. Lipschitz, Lane, and Mourmouras (2002) present the theoretical background for the surge of inflows to transition economies, and argue that the potential for overwhelming capital flows should be seen as intrinsic to the transition and convergence process. The paper presents the fundamental causes of the real appreciation inviting the inflows. ${ }^{5}$ The authors offer five main policy conclusions: (i) in addition to sound economic management, policy transparency and data dissemination are crucial; (ii) the open capital account reduces the independence of action for monetary policy, and fiscal policy becomes the main tool for stabilization policy; (iii) right sequencing of capital account liberalization is important, and long-term capital movements should be liberalized before short-term transactions; (iv) a strong regulatory and supervisory framework has to be set up before the capital account is fully liberalized, and special attention has to be paid to avoid excessive corporate foreign exchange exposure; and (v) although the choice of exchange rate regime cannot eliminate the problem of persistent capital flows, in most circumstances, a floating regime will make the country less vulnerable than a pegged regime, as more exchange rate variance is a disincentive to large foreign exchange exposure.

Buiter and Taci (2003) review the experience with capital flows in the entire transition country group, that is, for Central and Eastern Europe, the Baltic states, Southeastern Europe, and the Commonwealth of Independent States for the 1991-2001 period. The paper focuses on the link between capital flows and the financial sector, and gives an account of the development of different segments of the financial sector. The authors identify four remaining challenges to the stability of the financial sector in an environment of increasing integration into international capital markets: (i) strengthening prudential supervision and regulation; (ii) improving risk management of both individual institutions and supervisory

\footnotetext{
${ }^{5}$ The Balassa-Samuelson effect behind the trend real appreciation in transition economies is extensively researched. For a recent comprehensive survey see Égert (2004).
} 
agencies; (iii) improving transparency and disclosure of financial activities and market discipline; and (iv) enhancing the effectiveness of the legal framework.

Though not directly focusing on transition economies, Ishii and others (2002) is another highly relevant paper that concentrates on the linkages between capital account liberalization and financial sector stability. The paper gives operational advice on the sequencing of liberalization based on country experiences, with Hungary from the transition country group as one of the case studies. The paper stresses the need to properly sequence and coordinate capital account liberalization with other reforms to reduce the likelihood of external and financial sector instability.

Studies on the effects of the bank lending component of capital flows have proliferated recently; most of them have focused on the Asian crisis, but some of them investigate bank lending to transition economies. Buch and Lusinyan (2002) present an empirical investigation of the determinants of short-term capital flows based on cross-section data for international bank lending, and domestic and international debt securities. Based on the results, in-sample forecasts are performed for the (then) accession states and old members of the EU. The paper finds that the share of short-term debt increases with the state of development of the economies, and countries with pegged exchange rates have smaller shares of short-term debt securities. EU membership was not found to be statistically significant for the share of short-term bank lending, whereas it was negative for short-term domestic debt. The latter finding was not surprising, as macroeconomic stability in the old members states allowed for the development of mature domestic debt markets with higher average maturities than in transition countries, where debt maturities have been lengthening only gradually owing to higher inflation and macroeconomic uncertainty.

Buch, Heinrich, and Piazolo (1999) and Buch and Heinrich (2002) analyze the nature of financial flows to transition economies in the context of EU integration. The latter paper finds that, while in quantitative terms, (then prospective) EU accession economies had already achieved fairly high financial integration with international capital markets by the end of the 1990s, the structure of their capital flows was rather different from that of more developed economies. Along with further rises in capital flows, the major impact is likely to be a change in the structure of capital flows toward securitized financial assets, as transition countries join the EU. The authors point out that whereas portfolio inflows have been dominant in developed economies, developing countries have relied on portfolio capital, FDI, and other investments (bank lending and trade credits) in the 1990s. A closer look at transition economies reveals that-with the exception of Hungary-portfolio investment was even less important for this group than for developing and emerging countries in general between 1990 and 1999. ${ }^{6}$

\footnotetext{
${ }^{6}$ Buch and Heinrich (2002) p. 9.
} 
The process of capital account liberalization in individual transition countries has been analyzed in several case studies, a collection of which can be found in Bakker and Chapple (2003), where the experiences of Poland and Hungary are presented in detail. Nord (2003) characterizes Hungary as a good illustration of gradual capital account opening, and emphasizes that the credibility of Hungary's approach depended critically on supportive macroeconomic and structural policies. It argues that the capital controls maintained by Hungary - particularly on the short end — were more akin to "throwing sand in the wheels" than strict and effective controls, and overall do not appear to have discouraged foreign investment. On the contrary, they are likely to have had the positive effect of contributing to macroeconomic stability. Sadowska-Cieslak (2003) argues that Poland's similar, gradual approach to capital account liberalization, which was closely coordinated with macroeconomic developments and monetary and exchange rate policies, was also the right strategy. This cautious attitude helped the Polish economy to avoid currency and financial crises.

Research on the effectiveness of capital controls in Slovenia-the only EU8 country to introduce major capital controls_-found mixed results. Buch and Hanschel (1999) find that although the unremunerated reserve requirement (URR) in Slovenia was not effective in reducing total inflows, it was somewhat successful in changing their composition by discouraging short-term inflows. While the share of short-term credits in total foreign loans increased considerably between 1994 and 1998 in most other countries in the region, the reverse was true in Slovenia. In mid-1998, short-term credits accounted for only 18.5 percent of foreign bank loans, which was less than half of the values observed in the peer group. ${ }^{7}$ According to Caprirolo and Lavrac (2002), one of the most successful measures introduced was the requirement for banks to balance additional liabilities abroad with foreign claims as of July 31, 1996. This restriction virtually prohibited banks from borrowing abroad. The introduction of custody accounts was also quite effective in reducing nonresidents’ portfolio investments.

\section{DifFERENCES AND SimilaritiEs OF CAPITAL ACCOUNT LiBERALIZATION IN THE EU8}

During the 1990s, the EU8 countries were transitioning from command economies to market-based economies, and as a first step they had to establish current account convertibility. The obligations of the IMF's Article VIII were accepted in all EU8 countries between 1994 and 1996. The approach to capital account liberalization was more heterogeneous owing to each country's different starting conditions and macroeconomic developments during the transition period.

Prospective EU accession served as the ultimate anchor for capital account liberalization for transition economies. EU candidate countries have to fully liberalize their capital account by the time of EU accession at the latest, as the free movement of capital is one of the major

\footnotetext{
${ }^{7}$ See Table 3 in Buch and Hanschel (1999).
} 
principles of the EU. ${ }^{8}$ The EU acquis, however, do not contain legal obligations or procedural steps on the sequencing of capital account liberalization for candidate countries. Unless they finished the liberalization process beforehand, candidate countries need to commit themselves during negotiations for EU membership to a schedule of capital account liberalization during negotiations for EU membership from which they are not expected to deviate, except in circumstances undermining the conduct of monetary and exchange rate policies. ${ }^{9}$

The aspiration of some of the EU8 countries for OECD membership was also an important factor in opening up the capital account, as documented by Thiel (2003). The Czech Republic, Hungary, Poland, and the Slovak Republic applied for OECD membership in 1993-94. Along with EU negotiations, OECD accession discussions provided the roadmap for capital account liberalization in these four countries, as they were required to specify a timetable for removing the remaining restrictions. OECD members have to eliminate restrictions on capital movements and invisible transactions between one another, but they have the right to proceed gradually through a process of lodging and maintaining reservations. These reservations against specific operations on the liberalization lists of the Capital Movements Code go through a peer review process that assists countries to perform a thorough assessment of the macroeconomic environment, the financial system, and the potential policy measures. OECD talks proved to be very useful for the four countries in formulating their capital account liberalization strategies.

Although at the beginning of the transition process - the first half of the 1990s - capital account liberalization was generally viewed as beneficial by economists, international financial institutions, and the transition countries themselves, EU8 countries did not take a uniform view towards the speed and sequencing of liberalization. ${ }^{10}$ Despite the general view that tended to emphasize the advantages of capital account liberalization, in the first half of the 1990s no clear guidance was given on the operational aspects of this process, namely, the pace and sequencing of the removal of restrictions. The IMF encouraged capital account liberalization, but the process was mostly driven by the country authorities' agenda, which was in some cases ideological_-promoting fast liberalization in all areas, for example, in Estonia_ - and in other cases more pragmatic_continuously adjusting the liberalization of the capital account to macroeconomic developments, for example, in Poland.

\footnotetext{
${ }^{8}$ The relevant EC Treaty provisions governing the freedom of capital movements can be found in Articles 56 EC to 60 EC (formerly Articles 73b to 73h of the EC Treaty). According to Article 56 EC: " 1 . Within the framework of the provisions set out in this Chapter, all restrictions on the movement of capital between Member States and between Member States and third countries shall be prohibited.”

${ }^{9}$ All new member countries were granted some transitional arrangements, mostly related to the acquisition of agricultural and forestry land, as well as real estate.

${ }^{10}$ See the IMF Independent Evaluation Office (2005) on the evolution of the IMF's and the economic literature's approach to capital account liberalization.
} 
Two main groups can be distinguished among EU8 countries: rapid liberalizers - the Czech Republic, Estonia, Latvia, Lithuania_-and cautious liberalizers-Hungary, Poland, the Slovak Republic, and Slovenia. Different starting conditions played an important role in developing a country's liberalization strategy. For instance, because relatively high external debt in Hungary and Poland made these countries more vulnerable to external shocks, their authorities adopted a cautious attitude toward liberalizing capital flows.

EU8 countries displayed some similar patterns as well. One important feature of the liberalization process in EU8 countries was that the countries tended to liberalize inflows before outflows. This approach was mainly attributable to the initial uncertainty about the success of the transformation. In the first years of transition, the authorities feared that high inflation and depreciating currencies might trigger capital flight. The relatively fast macroeconomic stabilization in most of the countries dispelled this fear, and, from the second half of the 1990s onwards capital inflows caused more difficulties than potential outflows.

\section{A. Rapid Liberalizers}

The Czech Republic was a pioneer among EU8 countries in achieving a high degree of liberalization of its capital account relatively early in the transition process. As in other countries, the liberalization of inflows was somewhat faster than the removal of outflow restrictions, which indicates that the authorities were more concerned about potential outflows than inflows.

As in other cases, FDI was the first major item to be liberalized in the early 1990 s, $^{11}$ and a de facto liberal approach was already being applied also to foreign credits of banks and companies in 1994-95. Most capital transactions were de jure liberalized with the enactment of the new Foreign Exchange Act in September 1995, including short-term portfolio and credit inflows. One of the reasons for accelerated capital account liberalization was OECD accession, which took place in December 1995. The 1995 Foreign Exchange Act contained a safeguard clause that allowed the central bank to introduce deposit requirements on capital inflows if necessary and to stop certain transactions entirely. Although this clause has never been activated, the central bank did instruct commercial banks not to lend to nonresidents in domestic currency during the May 1997 currency crisis. ${ }^{12}$

The remaining restrictions following the 1995 liberalization round pertained mostly to outflows, such as the issuance of debt and money market securities abroad by residents, and the opening of accounts by residents abroad, as well as financial derivatives transactions. To comply with OECD membership obligations and in the framework of EU accession negotiations, the Czech authorities adopted a five-year program in early 1996 to eliminate the remaining limitations. As of January 1, 1999, restrictions on foreign security transactions,

\footnotetext{
${ }^{11}$ Restrictions on FDI into the banking industry and aviation were maintained.

${ }^{12}$ Buch and Lusinyan (2002).
} 
financial derivative operations, the sale of collective investment instruments by nonresidents, and the extension of financial credits by residents to nonresidents were abolished. The issuance of debt securities abroad by residents and the opening of deposits by residents abroad were liberalized as of January 1, 2001.

There are signs that capital account liberalization in the Czech Republic was premature and played a major part in the May 1997 currency crisis, when monetary authorities were forced to abandon the fixed exchange rate system. The two years preceding the crisis witnessed heavy inflows, mostly financial credits with increasingly short-term maturities. ${ }^{13}$ The capital account was liberalized and foreign investment flowed in against a backdrop of immature financial markets and incomplete structural reform.

The Baltic countries_-Estonia, Latvia, and Lithuania-also belong to the group of rapid liberalizers. Estonia's liberal economic policy was also reflected in speedy capital account liberalization: by the end of 1994, nearly all controls on capital account transactions had been removed. Some minor limitations_-such as restrictions on pension funds' investments in nongovernment securities of certain countries and in foreign real estate-were eliminated later, but these were irrelevant in terms of managing capital flows. Latvia and Lithuania also removed barriers to capital mobility early in the transition phase, and by 1994-95 most restrictions on FDI, credit, and portfolio flows were gone. Like the other countries in the region, these two Baltic countries also retained some restrictions on real estate investments and pension fund investments for some years. They entered the EU with transitional arrangements for the acquisition of agricultural and forestry land.

Thus, by late 1995 the Czech Republic and the Baltic countries had opened up their capital account to a high degree to interest-rate-sensitive and equity flows. This caused some problems in the Czech Republic_culminating in the May 1997 currency crisis_but posed no particular difficulties for the Baltic countries.

\section{B. Cautious Liberalizers}

Hungary began its transition in the first half of the 1990s with high external debt, low foreign exchange reserves, and growing macroeconomic imbalances. As a result, Hungarian authorities adopted a very cautious attitude toward capital account liberalization. ${ }^{14}$ Pre-1995, the only major item to be liberalized was inward FDI (rather early, in 1989), and this period was mostly spent gradually liberalizing the current account. Hungary submitted its official application to the OECD in December 1993, but no major progress was achieved in capital account liberalization before 1995.

\footnotetext{
${ }^{13}$ See Christensen (2004)

${ }^{14}$ For more details on Hungary’s liberalization process see Nord (2003). An assessment of the Hungarian capital account liberalization in connection with financial sector reform can be found in Ishi and others (2002).
} 
The next phase commenced with the new Foreign Exchange act of January 1996, which was a major step toward current and capital account liberalization. The main principle guiding this round of liberalization was to liberalize long-term flows before short-term flows. Hungary's obligations related to OECD accession — which it joined in May 1996 — and the improving macroeconomic environment played an important role in accelerating liberalization. Among the most important items to be liberalized in 1996 were the sales and issues of securities to nonresidents with original maturities of more than one year. ${ }^{15}$ The July 1996 liberalization of long-term outflow items did not have much noticeable effect, as the improving macroeconomic conditions made domestic investment more attractive. The gradual easing of remaining foreign exchange restrictions and small steps to liberalize the capital account characterized the period until June 2001, when full liberalization eventually took place. ${ }^{16}$ Full liberalization was preceded by a change in the exchange rate regime, as the fluctuation band of the Hungarian forint's exchange rate was widened from \pm 2.5 percent to \pm 15 percent.

In addition to the surge of inflows into the government securities market, there are other indications that the remaining capital account restrictions were increasingly ineffective. The London offshore forint market allowed nonresidents to take positions on the currency, which contributed to speculative pressures at times. The dominance of foreign ownership in the financial sector also somewhat diminished the effectiveness of restrictions, as commercial banks could swiftly react to developments in domestic financial markets and often took positions on expected exchange rate movements. They were the biggest players in the derivatives markets as well. However, the restrictions on lending to nonresidents in domestic currency and on their participation in the derivatives market somewhat protected the domestic markets from speculative moves.

Poland also adopted a gradual schedule of capital account liberalization, demonstrating a preference for long-term flows against short-term flows, and liberalizing inflows before outflows. ${ }^{17}$ High external debt, very high inflation, and recurrent devaluations caused the authorities to proceed very cautiously in removing restrictions. The liberalization was coordinated to a high degree with macroeconomic developments, especially with monetary and exchange rate policy.

\footnotetext{
${ }^{15}$ In January 1996, the liberalization encompassed securities with a remaining maturity of one year or more. However, owing to technical difficulties in implementation, this was changed to securities with an original maturity of one year or longer in July 1996.

${ }^{16}$ In this final round of liberalization, restrictions on the following major capital transactions were abolished: (i) short-term foreign exchange loans from nonresidents to residents; (ii) short-term foreign exchange and local currency loans from residents to nonresidents; (iii) sales and purchases of non-OECD countries' shares and bonds; and (iv) the sales and purchases of short-term instruments of OECD countries.

${ }^{17}$ See Sadowska-Cieslak (2003) for more details on capital account liberalization in Poland.
} 
FDI inflows and some portfolio inflows were the first items to be liberalized during 1990-94. In the government securities market, foreign investors were initially allowed to purchase securities with maturities over one year only, but this restriction was removed in 1993. This move opened up the channel for interest-rate-sensitive inflows for nonresident investors, but inflows into treasury securities were limited in the first few years, given the macroeconomic risks and the limited amount of securities available. Portfolio investment on the Warsaw Stock Exchange was liberalized in September 1994.

The liberalization of capital movements speeded up somewhat during the period of OECD accession negotiations between November 1994 and November 1996. A new Foreign Exchange Law was passed in December 1994 (though still restrictive by OECD standards), and, following the acceptance of Article VIII obligations in June 1995, a host of transactions were liberalized, including commercial credits, most FDI outflows, and long-term portfolio investment in OECD markets. Following OECD accession, the authorities liberalized longterm flows first, removing restrictions on inflows before liberalizing outflows. They liberalized certain transactions gradually, increasing the ceiling on these transactions step-bystep after ensuring that the flows did not disrupt monetary policy. Given the large current account deficit and wide interest rate differentials, Poland postponed the elimination of several short-term restrictions in early 1999, when the new Foreign Exchange Law came into effect. Eventually, in October 2002, all remaining short-term restrictions were eliminated.

As in the case of Hungary, the prolonged process hid the fact that restrictions on capital flows were not only not as stringent as they might seem, but also were increasingly ineffective. One of the important items, portfolio investment in treasury securities, was liberalized rather early, and it was a major cause of fluctuation in capital flows. The offshore zloty market in London was also occasionally a source of speculative pressures.

The liberalization of the Slovak Republic's capital account has received less attention than that of the other countries, mostly because until recently capital inflows to the country have been smaller than to other advanced Central European economies. This was mostly because the Slovak Republic's political instability and sluggish economic reforms until 2000 were not favorable to FDI and other inflows. The ultimate anchor of the capital account liberalization was EU membership, and the details were driven by OECD talks, as in the case of the other Central European countries.

The Slovak Republic pursued a gradual liberalization strategy following similar principles as the other "cautious" transition countries: liberalization of long-term before short-term flows, and preference for inflows to outflows and FDI to financial credits. Following the liberalization of inward FDI in the early 1990s, a further few items were liberalized in 1996 related to the OECD accession negotiations. ${ }^{18}$ After this liberalization round, however,

\footnotetext{
${ }^{18}$ The liberalization included direct investment in OECD countries, financial credits with maturities of five years and longer from residents to nonresidents in OECD countries, and financial credits with maturities of three years and longer from nonresidents to residents.
} 
economic reforms and capital account liberalization slowed, and the Slovak Republic missed the 1995-96 OECD accession wave. However, from 1999, when the reform process got a boost, capital account liberalization accelerated. In the 2000 amendment to the Foreign Exchange Act, the remaining restrictions on medium- and long-term capital transactions were lifted including financial credits and the issue of Slovak securities abroad with maturities of one year and longer.

The Slovak Republic joined the OECD in 2000, and, as a response to EU and OECD commitments, it developed a plan for removing the remaining restrictions by the time of EU accession. It adhered to this plan in the run-up to EU accession. Short-term financial credits were liberalized in 2001, and financial derivatives were liberalized and the remaining restrictions on securities transactions removed as of January 1, 2003. The liberalization of several major items was left to the last minute: as of January 1, 2004, the repatriation obligation was abolished, and resident operations with foreign deposit accounts and foreign currency operations were liberalized.

The Slovak Republic's liberalization of the capital account was among the slowest in the EU8 group. Managing capital inflows did not pose significant problems in the 1990s, owing to the slow reform process. Recently, substantial FDI inflows have been complicating the conduct of monetary policy. Compared with other Central European countries, interest-ratesensitive inflows have been relatively modest in the Slovak Republic, mainly because of the undeveloped nature of its capital markets.

Slovenia was the only EU candidate country to introduce major capital controls and one of the slowest to liberalize its capital account. ${ }^{19}$ The restrictions were introduced because domestic residents were borrowing heavily abroad in the 1990s in response to very large interest rate differentials. Unlike in other accession countries, even FDI inflows faced substantial restrictions during the $1990 s .{ }^{20}$ Capital account measures had three major phases: capital controls in 1995-99, liberalization of credit operations in 1999-2000, and full liberalization in 2001-02.

In the first phase, interest-rate-sensitive capital inflows-mainly in the form of domestic residents' borrowing abroad-intensified in 1994-96 due to large domestic/foreign interest rate differentials. ${ }^{21}$ The potentially destabilizing effect of capital inflows and high

\footnotetext{
${ }^{19}$ For more details on Slovenia's capital account liberalization process and capital flows in the 1990s, see Caprirolo and Lavrac (2002).

${ }^{20}$ The financial sector has been one of the sectors where foreign ownership was discouraged, and the asset share of state-owned banks was still around 50 percent in 2002.

${ }^{21}$ The differential between bank lending rates in Slovenia and LIBOR+depreciation was 15-25 percent in 1994-95 and around 10 percent in 1995-99.
} 
sterilization costs had been a major concern for monetary authorities and from 1995 on Slovenia introduced the following restrictions on capital flows: ${ }^{22}$

- $\quad$ February 1995. Introduction of a 40 percent unremunerated reserve requirement (URR) in tolar on foreign non-trade-related loans with a maturity of less than five years. For longer maturities, the deposit requirement is only 10 percent.

- December 1995. Imposition of a requirement on foreign exchange offices to balance their daily sales and purchases of foreign currency.

- July 1996. Imposition of a requirement on banks to balance any additional liability in foreign currency beyond their position as of July 31, 1996 with corresponding claims in foreign assets.

- $\quad$ August 1996. Lengthening of the maturity of loans subject to the URR to seven years.

- $\quad$ February 1997. Imposition of a requirement on foreign portfolio investments to be conducted through (costly) custody accounts with a fully licensed bank. The cost is borne by foreign portfolio investors when selling such securities to residents earlier than six months after their purchase.

- January 1999. Reduction of the URR to zero (although the system is not abolished in order to reserve the right to reimpose a deposit requirement in case of monetary and exchange rate difficulties).

In the second phase, 1999-2000, restrictions were removed on credit operations, but restrictions on short-term capital flows were retained. In June 2000, a timetable was set for the liberalization of remaining restrictions, according to which custody-account-related restrictions were to be eliminated at the end of 2002. In the third phase, the capital account was fully liberalized. Restrictions on portfolio inflows with maturities above six months were eliminated in July 2001. Liberalization progressed ahead of schedule, and, as of January 1, 2002, all restrictions on cash transactions and on securities operations were abolished, thus achieving almost full liberalization of inflows. Following the liberalization of credit operations, financial credit inflows increased significantly, but portfolio inflows still remained subdued. In fact, the elimination of restrictions on investment in foreign securities by mutual and investment funds in 2004 led to appreciable increase in portfolio outflows.

Slovenia's case is rather different from other countries in the region. Capital controls were installed mainly as a response to inflows induced by persistent foreign borrowing by domestic banks and enterprises. This is in contrast with other countries in the region experiencing heavy inflows, where the main concern of monetary authorities was the inflow of interest-rate-sensitive portfolio investment by nonresidents, which is potentially more

\footnotetext{
${ }^{22}$ Based on Caprirolo and Lavrac (2002).
} 
destabilizing and highly mobile. The small size of its capital markets made Slovenia less vulnerable to portfolio flows than the bigger countries in the peer group, such as the Czech Republic, Hungary, and Poland.

\section{CAPITAL Flows AND FinANCIAL MARKETS}

FDI has been the largest component of capital inflows (US\$134 billion) followed by other investment (US\$41.4 billion) and portfolio investments (US\$28.2 billion) in EU8 countries in the period 1995-2003 (Figure 1 and Table 1). ${ }^{23}$ Among portfolio items, inflows into debt securities far outweighed those into equities. The composition of private capital flows is a good illustration of the structure of the financial system in transition economies, characterized by (i) the dominant role of the banking sector in intermediation compared with capital markets, and (ii) the more developed nature and larger size of fixed-income markets (almost exclusively government securities markets), compared with stock markets. ${ }^{24,25}$ In what follows, the focus is on other investment and portfolio flows, as these flows posed considerably more difficulties to monetary authorities in terms of economic policy, external vulnerability, and financial stability than direct investment flows did.

Table 1. EU8 Countries: Breakdown of Net Capital Inflows into EU8 Countries, 1995-2003

(Percent of total, unless otherwise noted)

\begin{tabular}{lr|rrrr}
\hline & $\begin{array}{c}\text { Total amount } \\
\text { (In billions of U.S. dollars) }\end{array}$ & $\begin{array}{c}\text { Foreign Direct } \\
\text { Investment }\end{array}$ & $\begin{array}{c}\text { Portfolio Investment } \\
\text { into Debt Securities }\end{array}$ & $\begin{array}{c}\text { Portfolio Investment } \\
\text { into Equity Securities }\end{array}$ & Other Investment \\
\hline Total cumulative inflow & & & & & \\
$\quad$ for EU8 & 202.89 & 134.0 & 19.3 & 8.2 & 41.4 \\
\hline Poland & 77.7 & 63.3 & 15.9 & 2.4 & 18.4 \\
Czech Republic & 43.9 & 81.6 & -9.9 & 6.6 & 21.7 \\
Hungary & 35.2 & 76.9 & 21.5 & 7.2 & -5.7 \\
Slovak Republic & 19.0 & 52.5 & 10.7 & 0.9 & 35.9 \\
Lithuania & 8.9 & 40.6 & 15.0 & 2.0 & 42.4 \\
Slovenia & 7.2 & 38.1 & 18.8 & -2.3 & 4.3 \\
Latvia & 5.8 & 48.3 & -19.2 & 1.0 & 69.3 \\
Estonia & 5.3 & 53.2 & 2.7 & 11.9 & 32.2 \\
\hline
\end{tabular}

Source: IMF, International Financial Statistics.

Note: Financial derivatives are not reported, as their weight is negligible.

\footnotetext{
${ }^{23}$ The total stock of FDI was around US\$170 billion for the EU8 countries at the end of 2003, somewhat larger than the cumulative inflows in the table, which presents data only the 1995-2003 period.

${ }^{24}$ The issuance of corporate debt and municipal and mortgage bonds has been negligible in economies in the first decade of transition. However, there are signs of some pickup in recent years, e.g., for the municipal bond market in the Czech Republic, the mortgage bond market in Hungary, and the corporate bond market in Poland.

${ }^{25}$ See, e.g., Buiter and Taci (2003) for an analysis of stock market capitalization in transition economies.
} 
Figure 1. EU8 Countries: Net Capital Flows, 1995-2003

(In millions of U.S. dollars)

\section{Czech Republic}

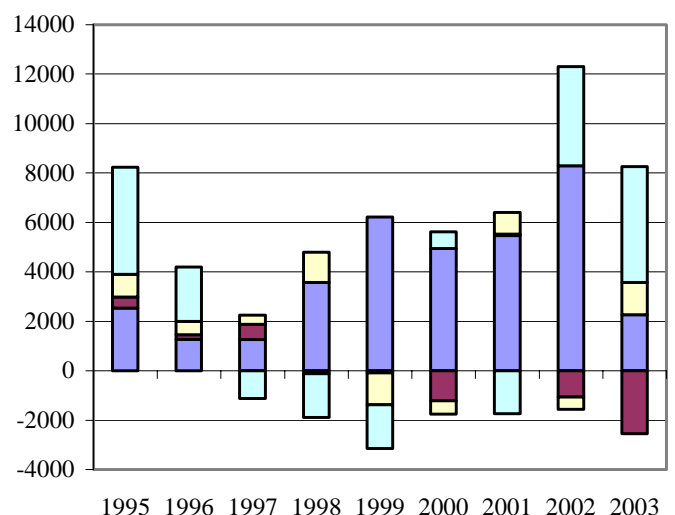

Hungary

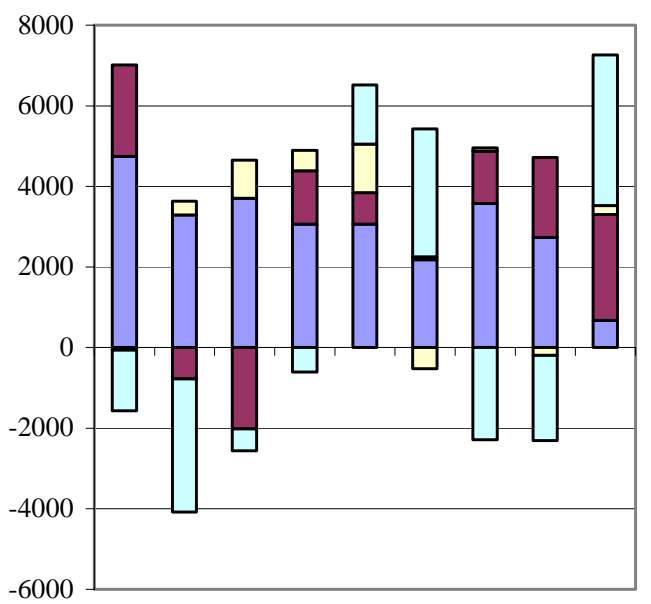

199519961997199819992000200120022003
Estonia

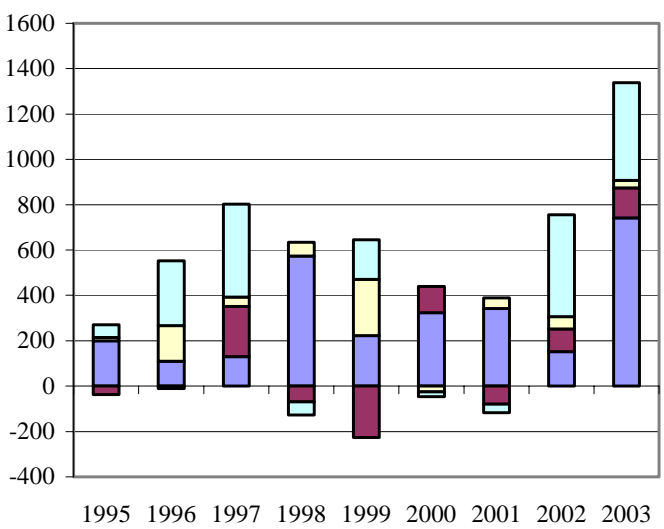

Latvia

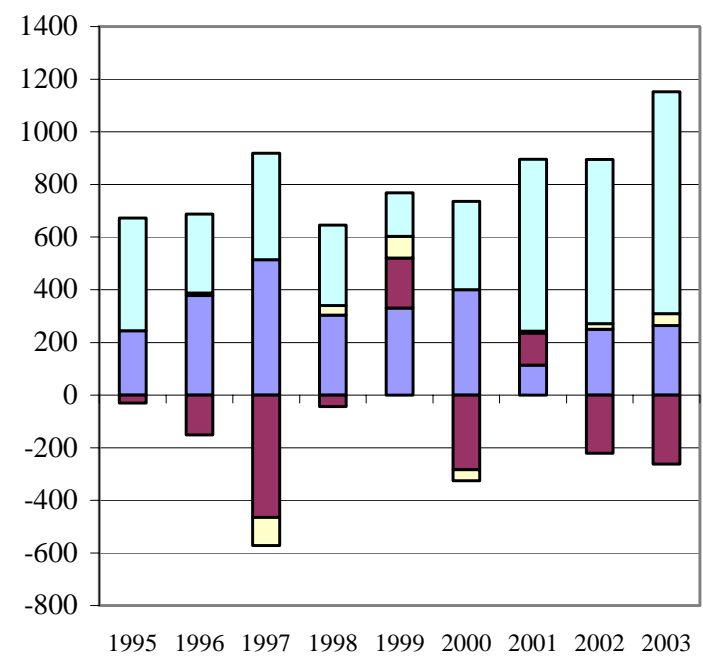

口Other investment

$\square$ Portfolio inv. into equity securities

$\square$ Portfolio inv. into debt securities

$\square$ FDI 
Figure 1. EU8 Countries: Net Capital Flows, 1995-2003 (concluded) (In millions of U.S. dollars)

Lithuania

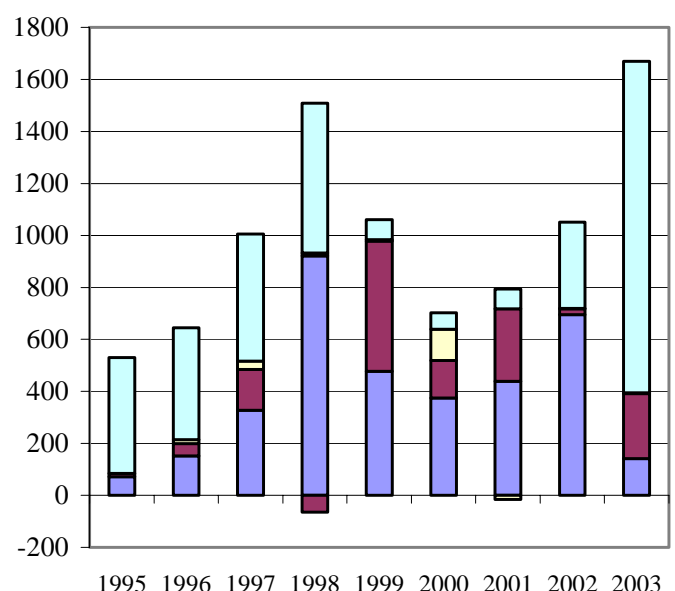

Slovak Republic

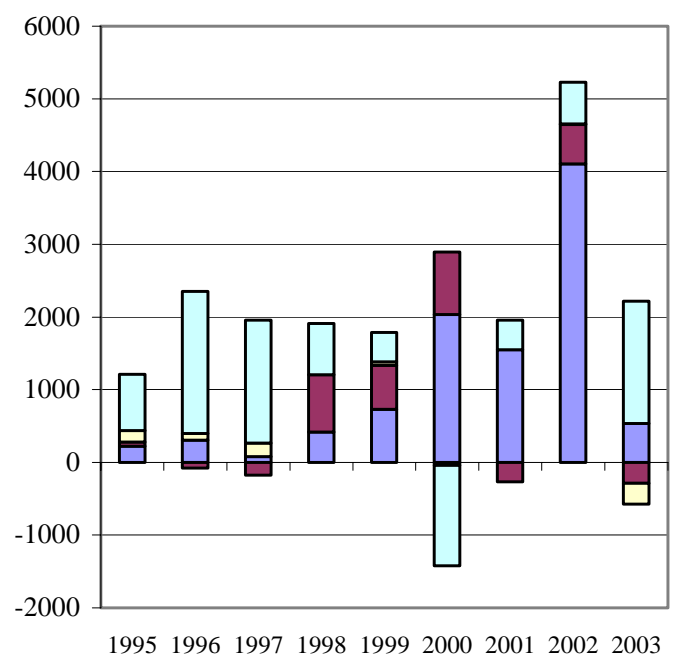

Source: IMF, IFS.
Poland

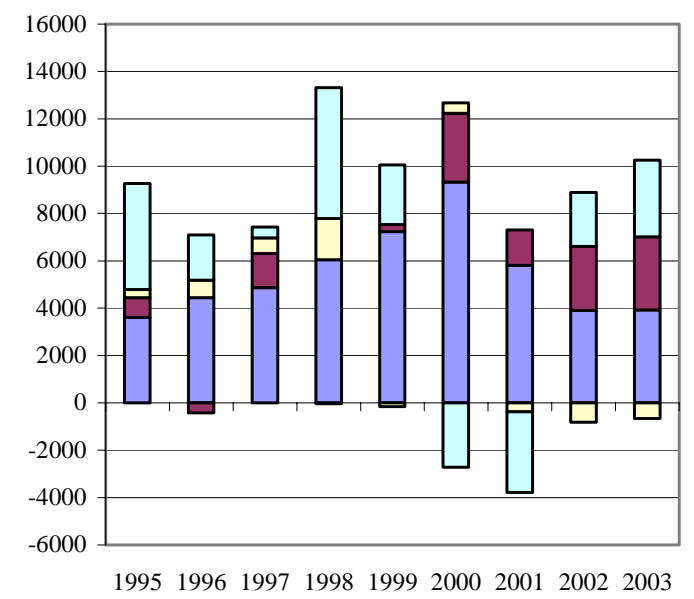

Slovenia

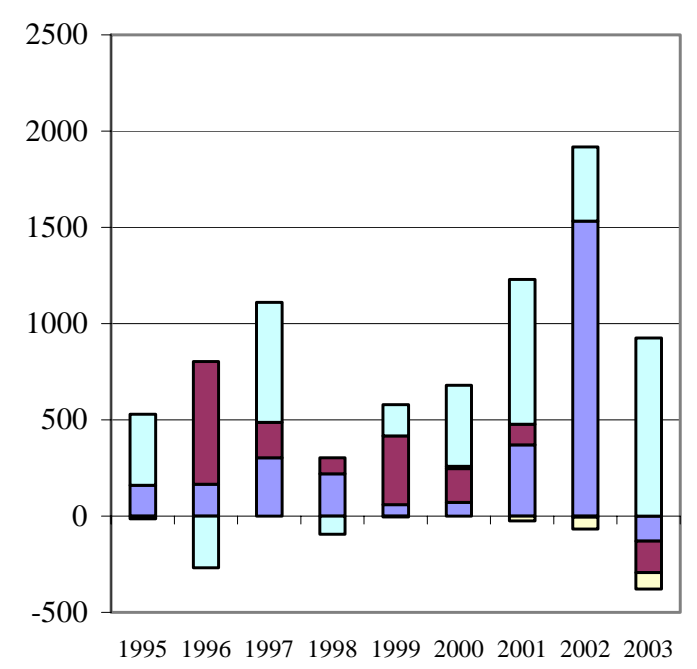

$\square$ Other investment

$\square$ Portfolio inv. into equity securities

$\square$ Portfolio inv. into debt securities 口FDI 


\section{A. Other Investment Flows}

The category of "other investment flows" recorded the second-largest volume after FDI. The major groups in this category are trade credits and loans (usually referred to as financial credits) as well as currency and deposits. Other investment flows are reported for the monetary authorities, general government, the banking sector, and other sectors (predominantly the enterprise sector). Although other investment inflows have been substantial for EU8 countries as a group, their share in total net inflows in 1995-2003 ranges from -6 percent (in Hungary) to 70 percent (in Latvia). The share of net financial and trade credit flows in total flows was significantly smaller in the larger Central European countries (the Czech Republic, Hungary, and Poland) than in the Baltic states and in the Slovak Republic and Slovenia. Financial credit flows intensified in the late 1990s in most countries - a development that is not only attributable to capital account liberalization, but also to successful macroeconomic stabilization and increasing financial deepening.

The sectoral breakdown of other investment flows reveals not only some common trends, but also some differences across countries during the period (Figure 2). Financial credit flows were channeled mainly through the banking sector in Estonia, Latvia, Slovenia, and Hungary. In the Czech Republic, Lithuania, and Poland, the enterprise sector received the bulk of the inflows, whereas in the Slovak Republic the shares of the banking and enterprise sector were roughly equal. The importance of foreign direct borrowing by the enterprise sector was more pronounced in the 1990s than in the current decade.

There were several reasons behind the substantial direct foreign borrowing by enterprises during the transition period. High inflation and nominal interest rates, coupled with trend real appreciation, increased the attractiveness of foreign-exchange-denominated borrowing.

Although bank restructuring and privatization were under way in most countries in the 1990s, domestic banks were burdened by large shares of nonperforming loans, relatively high reserve requirements, and low efficiency. ${ }^{26}$ This raised the cost of domestic borrowing for enterprises relative to foreign borrowing and explained the large spread between loans and deposits. Before the privatization and restructuring of large domestic banks, and the spread of syndicated loans, foreign-owned banks were often too small to satisfy the borrowing needs of their larger clients. These banks established links between domestic companies that were deemed creditworthy and the banks' foreign headquarters. Direct foreign borrowing was also related to FDI, as foreign-owned companies had easy access to foreign banks through their owners. Early enterprise restructuring increased the profitability and, thus, the creditworthiness of companies.

The cross-country patterns tend to confirm these hypotheses. The protracted bank restructuring process in the Czech and Slovak Republics contributed to high direct foreign borrowing by enterprises. High foreign ownership levels in the Polish and the Czech

\footnotetext{
${ }^{26}$ Non-performing loans were not as big a problem in Slovenia as in the other countries.
} 
enterprise sectors - among the top recipients of FDI in the region-from the early stages of transition onward led to easy access to foreign banks. The scarcity of large Estonian and Latvian companies likely contributed to the dominance of inflows through the domestic banking system in these countries given the transaction costs of direct foreign borrowing.

The effect of capital controls in Slovenia is not easily discernible, though they most likely contributed to the net outflow in 1996. Hungary was the only country experiencing a cumulative outflow from the enterprise sector; this is somewhat puzzling, as Hungarian companies would have been well-placed to have access to direct foreign borrowing, given the early restructuring of the sector and large FDI inflows. Most likely, the early and successful privatization and restructuring of the banking sector and the heavy competition for creditworthy corporate clients made direct foreign borrowing less attractive for Hungarian companies.

The banking channel of other investment flows became dominant in almost all countriesapart from Lithuania and Poland - from 2000 onward. Banking system restructuring and privatization were nearly completed in all countries, competition in the banking sector increased, reserve requirements were reduced, and nominal interest rates declined, thereby narrowing interest margins. ${ }^{27}$ As a result, a large part of former direct foreign borrowing by the enterprise sector was channeled through the banking system. In addition, declining profit margins in corporate lending prompted banks to increase lending to households and small and medium-sized enterprises, which had very low indebtedness. The ensuing fierce competition for market shares in retail banking led to credit booms in most countries, fuelled by financial inflows through the banking system. ${ }^{28}$ This surge of financial credit inflows was triggered mainly by the fight for market share and large profit margins in nascent markets, and not simply by interest rate differentials, which had declined substantially in most countries by this time.

Finally, a net outflow from monetary authorities and the general government of nearly US $\$ 10$ billion was recorded for the region as a whole during 1995-2003. This was driven by the external debt repayment of some countries: the cumulative net outflow reached US\$7.6 billion for Poland and nearly US\$3.8 billion for Hungary. However, the monetary authorities and the government were typically net borrowers in countries with lower public debt, such as the Baltic states and the Slovak Republic.

\footnotetext{
${ }^{27}$ The only exception is Slovenia where the largest banks (representing more than 40 percent of banks assets) remain state-owned.

${ }^{28}$ See Cottarelli, Dell’Ariccia, and Vladkova-Hollar (2003).
} 
Figure 2. EU8 Countries: Other Investment Flows, 1995-2003

(In millions of U.S. dollars)
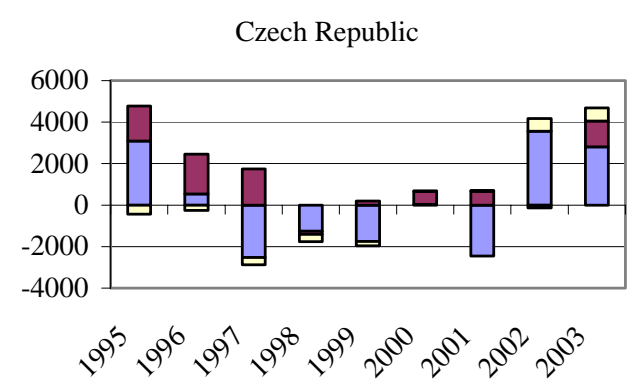

Hungary

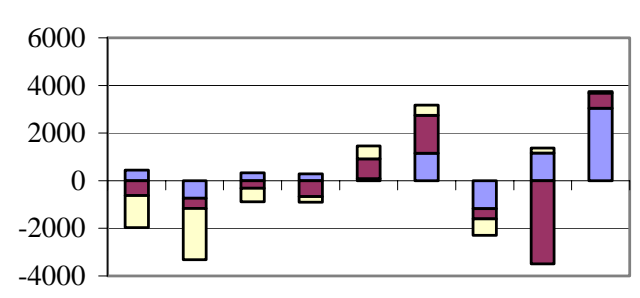

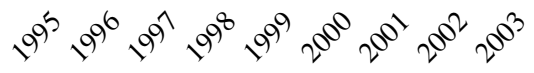

Lithuania

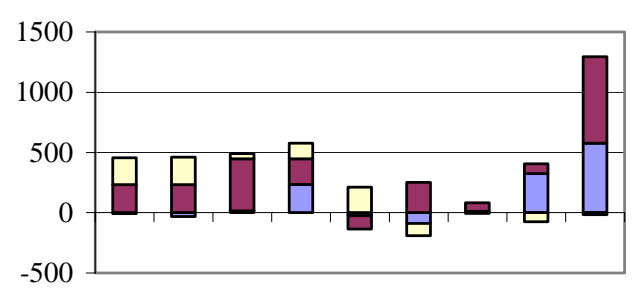

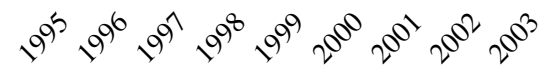

Slovak Republic

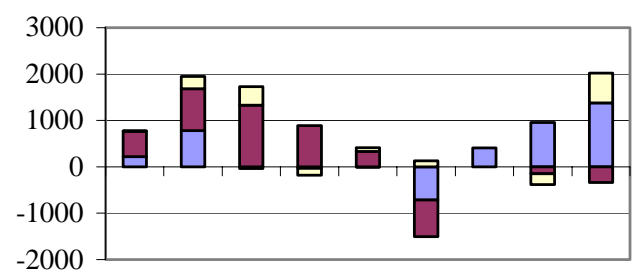

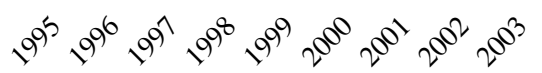

Source: IMF, IFS.
Estonia
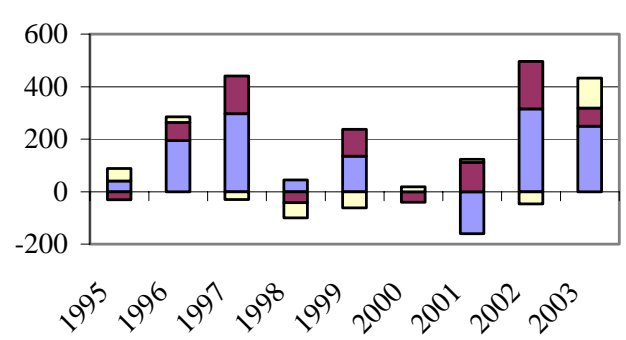

Latvia
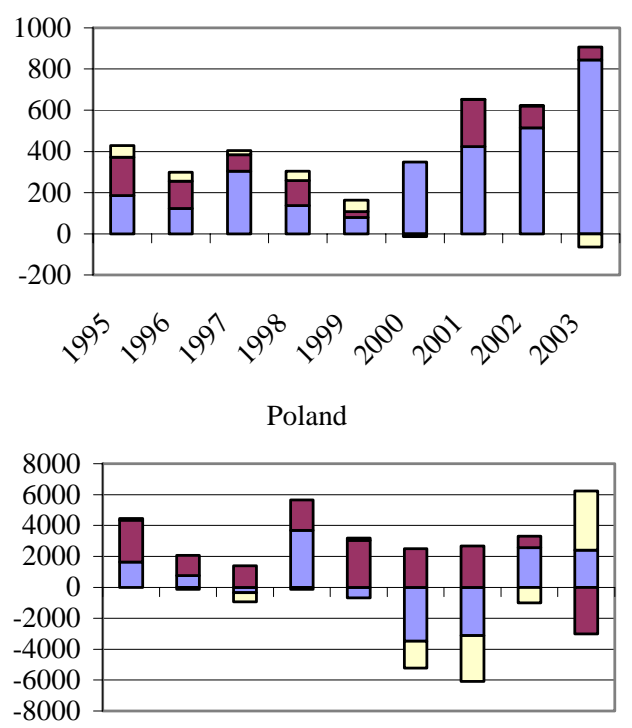

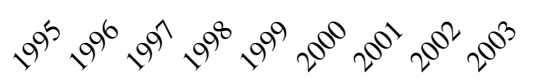

Slovenia

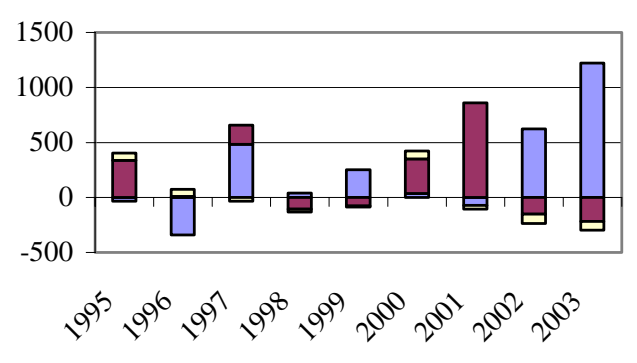

$\square$ Monetary authorities and general government

$\square$ Other sectors (enterprises)

$\square$ Banks 


\section{B. Portfolio Flows}

Considering the differences in the pace and sequencing of capital account liberalization, it is somewhat surprising that countries with cautious liberalization strategies have been the biggest recipients of interest-rate-sensitive portfolio inflows. This is an indication that other important factors are behind these flows besides capital account liberalization, and that the slow pace of liberalization amounted more to throwing sand into the wheels and tilting the composition of flows toward long-term securities than effectively preventing large interestrate-sensitive portfolio inflows. Indeed, as was noted above, the relatively early liberalization of Poland's and Hungary's government securities markets effectively opened up the channel for highly volatile and potentially destabilizing interest-rate-sensitive inflows, and the effect of the remaining restrictions - however numerous - was relatively minor.

For countries other than Hungary and Poland, the issuance or foreign-exchange-denominated bonds - mainly Eurobonds - was the primary source of portfolio investment in debt securities. Since the decomposition of portfolio inflows by currency denomination is not readily available, interest-rate-sensitive portfolio inflows will be approximated by nonresidents' investment in the domestic government securities market. ${ }^{29}$ Portfolio inflows into government securities are reflected in the growing share of nonresident holdings of these securities (Appendix Table A1).

Consistent with intuition, two factors have been crucial for attracting interest-rate-sensitive portfolio inflows: a wide interest rate differential and available financial assets to invest in (Table 2 and Figure 3). Poland and Hungary had sizable interest rate differentials until the early 2000s - corresponding to their slow disinflation process - coupled with relatively high domestic debt. For Slovenia, the interest rate differential was somewhat smaller, and its fixed-income market capitalization was substantially lower. The attractiveness of the Slovak Republic's high interest rate differential was offset by low fixed-income capitalization and political uncertainty. For these reasons, portfolio inflows were small in these two countries. Falling interest rates accompanying the 1997-99 rapid disinflation and recession made Czech debt securities unattractive, and the capital account mainly recorded portfolio outflows despite the sizable fixed-income market. Nonresident portfolio investors have been largely uninterested in Baltic debt securities given the low interest rates and low market capitalization.

\footnotetext{
${ }^{29}$ A more precise estimate would include other domestic fixed-income assets, such as corporate securities, as well as municipal and mortgage bonds. The importance of these assets, however, has been insignificant throughout the period compared with government securities, and data on them are very hard to come by.
} 
Table 2. EU8 Countries: Size of the Government Securities Market, 1997-2004

(Marketable securities in parantheses when available, in millions of U.S. dollars, unless otherwise noted)

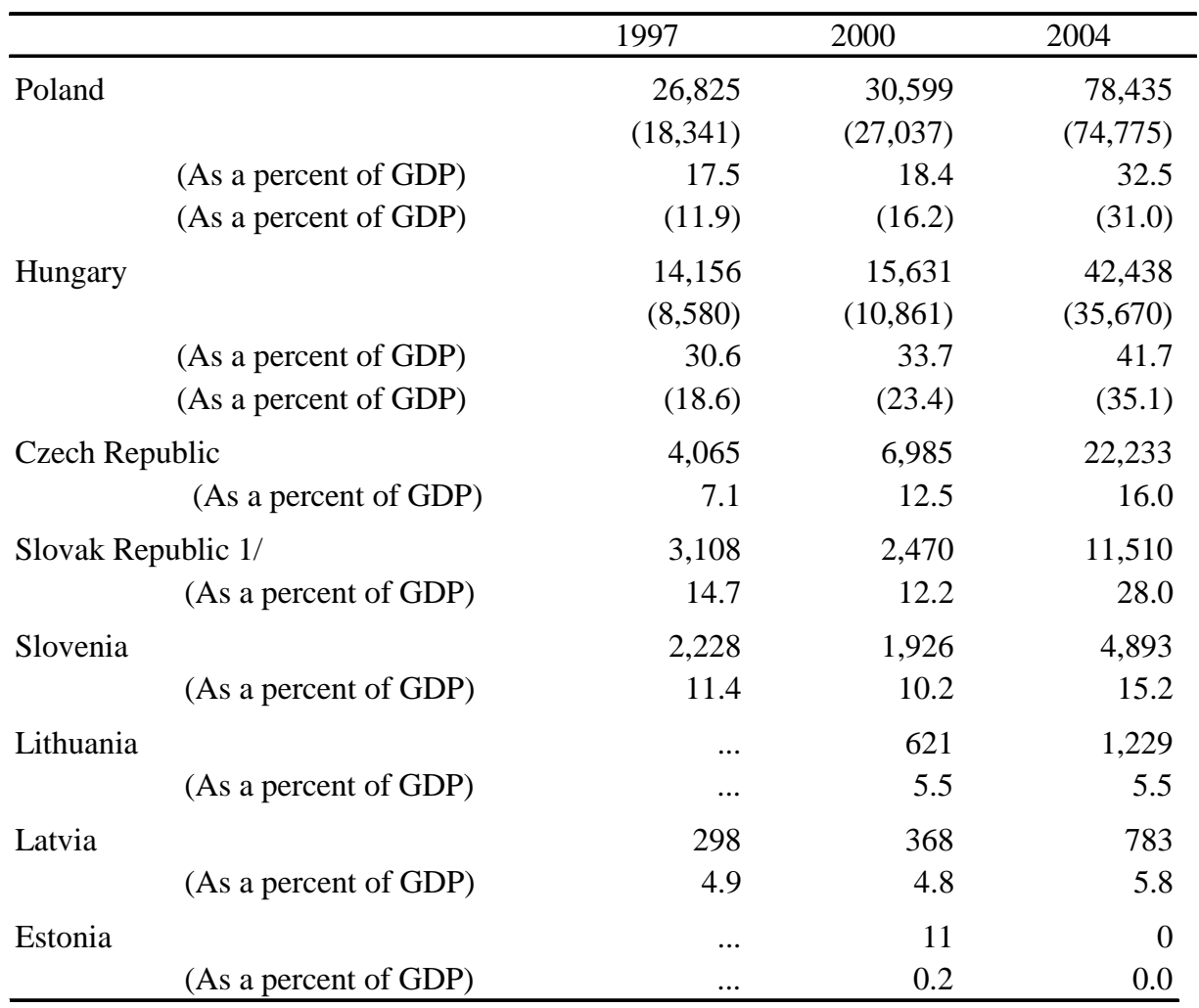

Sources: Ministries of Finance of the respective countries and the Government Debt Management Agency for Hungary.

1/ The jump in the Slovak Republic's domestic debt between 2000 and 2004 was mainly attributable to bank restructuring bonds. 
Figure 3. EU8 Countries: Interest Rate Differentials, 1995-2004

(In percent)

\section{Czech Republic}

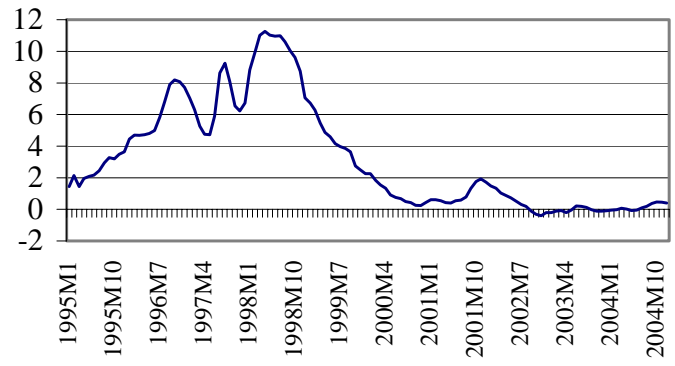

Hungary

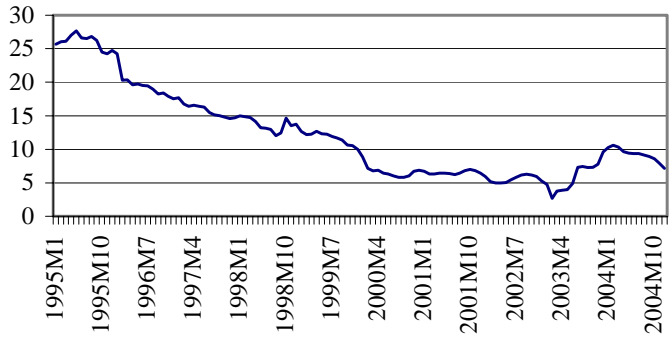

Lithuania

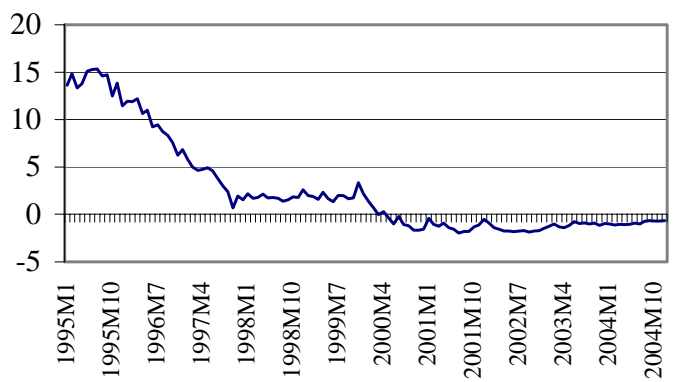

Slovak Republic

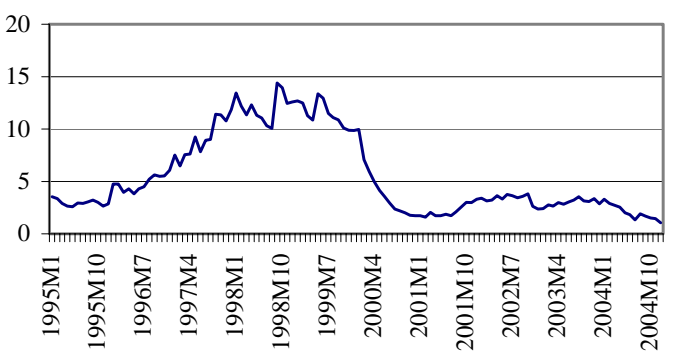

Estonia

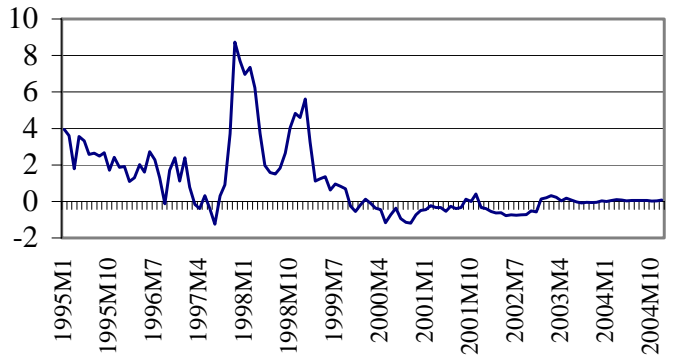

Latvia

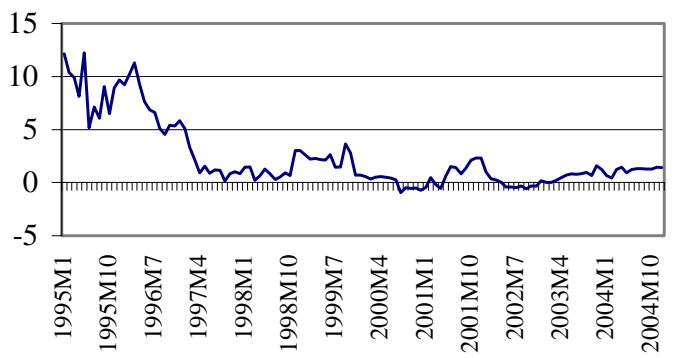

Poland

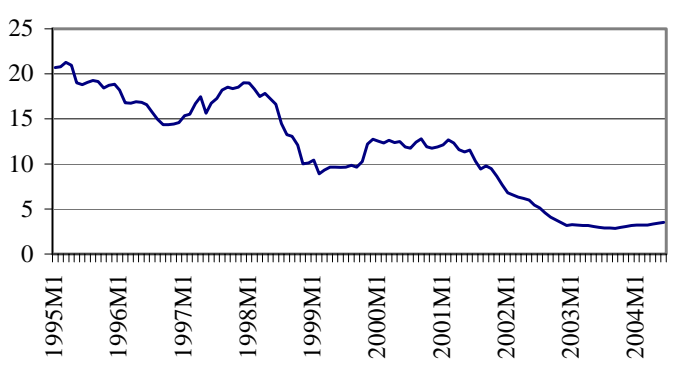

Slovenia

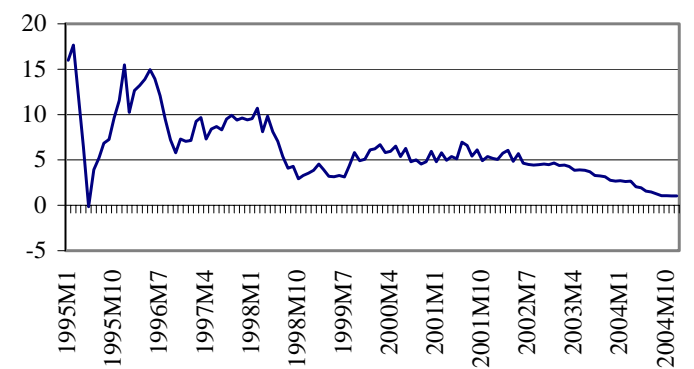

Sources: IMF, IFS ; and British Bankers' Association. Note: The panels depict the difference between local treasury bill rates (deposit rates if treasury bill rates are unavailable) and the three-month EUR Libor rate (ECU rate before 1999). 
The pattern of interest-rate-sensitive flows to EU8 countries indicates the significance of public debt and inflation. Countries with high public debt and slow disinflation-Hungary and Poland — were the most vulnerable to surges of portfolio inflows (Appendix Figures A1 and A2). Nonresident investors prefer markets with high liquidity, and the main (and, in most cases, only) liquid fixed-income instruments were government securities. Foreign participants in the domestic government securities market make the secondary market more liquid and financial services more sophisticated, which, in turn, attracts further inflows. High liquidity can be a mixed blessing, as Poland and Hungary found out during international capital market turbulence. Because foreign investors can liquidate their positions more easily, and with smaller losses in liquid markets, these markets tend to bear most of the burden in cases of regional outflows.

The pace of disinflation was also a major determinant for portfolio inflows as monetary authorities aimed to maintain positive real interest rates to fight inflation and encourage savings (Appendix Figure A2). The Baltic countries and the Czech Republic managed to achieve low inflation by 1999 and virtually eliminated the interest rate differential vis-à-vis euro rates (Figure 3). However, Poland, the Slovak Republic, and Hungary posted very high interest rate differentials (even after adjusting for exchange rate changes) in the 1990s, with nominal interest rates converging to euro zone levels only recently.

Expected exchange rate trends in transition countries have also made financial assets attractive. Trend real exchange rate appreciation driven by the Balassa-Samuelson effect was partly achieved through nominal appreciation in the Czech Republic, Hungary, Poland, and the Slovak Republic following the floating of their currencies. Despite this trend, exchange rates have been volatile, occasionally going through phases of depreciation (Appendix Figure A3). The Baltic countries successfully maintained fixed exchange rates, ${ }^{30}$ and Slovenia was the only country with a depreciating currency up to its EU accession.

In summary, a closer look at the data reveals that cautious liberalizers actually received larger portfolio inflows than rapid liberalizers. ${ }^{31}$ This outcome can be explained partly by differences in starting conditions (high domestic public debt) and partly by macroeconomic developments during transition (slower disinflation). Each country chose its pace of liberalization according to the perceived vulnerability to inflows, with the cautious liberalizers having more to worry about. Despite the large inflows and the increasing ineffectiveness of restrictions, the cautious approach to liberalization had some benefits. Where maintained, restrictions on lending to nonresidents in the domestic currency and on financial derivatives mitigated the volatility of capital flows and the scope for speculative attacks. In general, restrictions increased transaction costs, thereby reducing the gains from the interest rate differential.

\footnotetext{
${ }^{30}$ Estonia and Lithuania have currency boards, and Latvia has a hard peg.

${ }^{31}$ Both in absolute terms and relative to GDP.
} 


\section{Policy Responses to Capital Inflows}

EU8 countries used a variety of policy responses to capital inflows. Two main factors determined the policy response to inflows in EU8 countries: the nature of the inflows and the main macroeconomic goals. Capital inflows dominated by FDI usually require different responses than interest-rate-sensitive inflows or portfolio equity flows. Macroeconomic goals also differed across time and countries: some economies had prolonged struggles with inflation, while others worried more about growth after succeeding in bringing inflation down (Appendix Table A2). Most of the time, policymakers faced multiple challenges and had to establish priorities. Although this paper does not deal with the linkages between financial market stability and capital account liberalization, it is important to note that continuous improvements in prudential supervision and regulation have been crucial for the liberalization of the capital account in EU8 countries. In what follows, the policy responses are discussed in terms of the different policy options.

\section{A. Monetary and Exchange Rate Policies}

Monetary and exchange rate policies were the most common responses to capital inflows in the Central European countries. ${ }^{32}$ The main response to FDI inflows was sterilized intervention, both in flexible and fixed exchange rate settings. Fixed exchange rates were maintained by the Czech Republic until 1997, and the Slovak Republic until 1998. Slovenia maintained a heavily managed float throughout the period, whereas Poland and Hungary had crawling band regimes until 2000 and 2001, respectively, with Poland's band increasingly widening. Monetary authorities had to find a delicate balance among furthering disinflation, minimizing sterilization costs, and maintaining external competitiveness. Responding to these multiple challenges, countries chose the following mix of policies:

- Sterilized intervention was an active policy tool in Hungary-given the narrow band around the preannounced crawl-until the widening of the band in 2001. Poland phased out sterilized interventions earlier and stopped intervening in 1998 as part of its move to full exchange rate flexibility. Although it did not receive major interest-rate-sensitive inflows during the 1990s, the Slovak Republic's main response to inflows in its fixed exchange rate period was sterilized intervention. Slovenia also intervened heavily to keep the exchange rate on the desired path, motivated by real exchange rate considerations.

- Slowing the depreciation of the domestic currency by reducing the monthly rate of crawl was a prominent policy tool for disinflation in Hungary and Poland. The timing of crawl adjustments was usually determined by favorable inflation and current account developments, as well as by inflow pressures. In Poland, adjustments in the crawl were also accompanied by a gradual widening of the intervention band from \pm 2 percent in

\footnotetext{
${ }^{32}$ Monetary and exchange policies were not among the options possible for the Baltic countries because of their exchange rate regimes.
} 
1995 to \pm 15 percent in 1999 . Slowing the rate of depreciation was used for disinflation purposes in Slovenia as well.

- Cautious and gradual interest rate cuts following the path of disinflation were also an integral part of the policy mix. Central banks in the EU8 countries followed the market in most cases and aimed at maintaining low positive interest rates so as not to discourage savings.

The move to more flexible exchange rate arrangements was partly motivated by the increased volume of capital flows itself. Following the floating of their currencies, monetary authorities increasingly differentiated their policy responses depending on the nature of the inflow. After 1999, the Czech and Slovak Republics received increasing amounts of FDI to which they continued to react mostly with sterilized interventions. Poland and Hungary attracted large amounts of interest-rate-sensitive inflows in addition to sizable FDI inflows. Both countries abandoned the policy of sterilized intervention and allowed significant appreciations of their nominal exchange rates. ${ }^{33}$ At the same time, interest rate policy became more active in the three countries - the Czech Republic, Hungary, and Poland - that introduced formal inflation-targeting (IT) regimes.

Within the framework of IT, Poland, Hungary, and the Czech Republic followed different strategies: in Poland, interest rate policy was used for "pure" IT with little concern over the ensuing capital flows and exchange rate developments (Appendix Figure A3). The policy of nonintervention placed the costs of capital flow volatility on market participants and discouraged one-way bets on exchange rate developments. Hungary, on the contrary, used interest rate policy to try to keep the exchange rate in a relatively narrow band believed to be consistent with the inflation target; this strategy implied a belief in a strong exchange rate pass-through (Figure A3). The resolve to disinflate in the framework of IT was largely successful, and low-single-digit inflation was achieved in 2002 in Poland and in 2005 in Hungary (Figure A2). One of the consequences, however, was the very large inflow of interest-rate-sensitive capital accompanying the tight monetary policy. Interest rate policy in the Czech Republic's IT regime was less active, as it achieved low inflation soon after the introduction of IT.

Despite uncertain and likely weak interest rate transmission, the larger EU8 countries mostly avoided maintaining negative real policy rates for fear of their effect on inflation and savings, and of a sudden turnaround of capital flows. Among the Central European countries, only the Slovak Republic had prolonged periods of negative real policy rates, as it was more

\footnotetext{
${ }^{33}$ Though infrequently, they resorted at times of foreign exchange market stress, to intervention.
} 
concerned about the effect of large capital inflows on the exchange rate than about their potential effect on inflation (Appendix Figure A3). ${ }^{34}$

\section{B. Fiscal Policy}

The experience with fiscal policy in EU8 countries as a policy response to capital inflows is mixed. Fiscal policy can mitigate the effect of inflows on the real exchange rate, the current account, and inflation, however, it is a relatively inflexible policy tool because of the length of the budgetary procedures and the policy response lag. In addition, during the transition period fiscal policy had to deal with several major structural issues besides the cyclical position of the economy (such as pension reform, the reform of transfers and subsidies, major infrastructure investments, etc.). These circumstances made some countries more reluctant to tighten fiscal policy, even in the face of large capital inflows.

Two main groups can be distinguished in terms of fiscal policy: in the first groupcomprising Estonia, Latvia, Lithuania, and Slovenia-fiscal policy generally helped to offset the effect of capital inflows, whereas, in the larger Central European countries, looser fiscal discipline did not help and in some cases exacerbated the difficulties caused by the inflows. The Baltic states maintained prudent fiscal policies almost throughout the entire 1995-2003 period, as required by their currency board and hard peg arrangements, though there were episodes of fiscal loosening following the Russian crisis (Table 3). Slovenia also recorded only modest fiscal deficits during the 1995-2003 period. These countries were also helped by low public debt. Nevertheless, the fiscal stance was less of a direct response to the capital inflows than a general commitment to tight fiscal discipline throughout the period.

Table 3. Selected EU8 Countries: Government Balance - Countries with Prudent Fiscal Policies, 1995-2003 (As a percent of GDP)

\begin{tabular}{|c|c|c|c|c|c|c|c|c|c|}
\hline & 1995 & 1996 & 1997 & 1998 & 1999 & 2000 & 2001 & 2002 & 2003 \\
\hline Estonia & -0.5 & -1.6 & 0 & -0.3 & -4.3 & -0.6 & 0.4 & 1.4 & 2.9 \\
\hline Latvia & -3.9 & -1.7 & 0.1 & -0.8 & -3.9 & -3.0 & -2.0 & -2.3 & -1.6 \\
\hline Lithuania & -4.5 & -4.5 & -4.8 & -4.4 & -8.5 & -2.8 & -1.9 & -0.8 & -1.7 \\
\hline Slovenia & 0.1 & 0.2 & -1.2 & -0.5 & -0.6 & -1.3 & -1.3 & -1.5 & -1.4 \\
\hline
\end{tabular}

Source: IMF.

The larger Central European countries, however, posted rather large deficits, especially from 2001 (Table 4). There was no sign of fiscal tightening as a reaction to large capital inflows during most of the period in the four countries. The Slovak and Czech Republics tightened fiscal policy toward the end of the period, but this was not seen as a direct reaction to capital

\footnotetext{
${ }^{34}$ The Baltic countries also experienced periods of negative real interest rates. Though the fixed exchange rates and the currency boards were not in danger, low interest rates are likely to have contributed to the credit booms and ballooning current account deficits in these three countries.
} 
inflows. Loose fiscal policy contributed to slow disinflation in Hungary and the Slovak Republic, and to large current account deficits in the Czech and Slovak Republics, and Hungary (Appendix Table A2). The lack of fiscal response placed most of the burden of disinflation on monetary and exchange rate policies, especially in Poland and Hungary. Tight monetary policy in Poland in 1999-2001 and in Hungary after 2002 contributed significantly to increased portfolio inflows (Figure 1 and Appendix Figure A3). Having brought inflation down to low-single-digit levels, fiscal consolidation remains the biggest challenge to euro adoption in these four countries.

Table 4. Selected EU8 Countries: Government Balance - Countries with Loose Fiscal Policies, 1995-2003 (As a percent of GDP)

\begin{tabular}{lrrrrrrrrr}
\hline & 1995 & 1996 & 1997 & 1998 & 1999 & 2000 & 2001 & 2002 & 2003 \\
\hline Czech Republic & 0.2 & -0.4 & -1.2 & -0.6 & -1.6 & -3.3 & -5.0 & -6.6 & -6.0 \\
Hungary & -6.2 & -3.1 & -4.8 & -4.8 & -3.7 & -3.0 & -4.7 & -9.4 & -7.2 \\
Poland & -3.1 & -3.3 & -3.1 & -3.3 & -3.0 & -3.0 & -5.3 & -6.3 & -5.8 \\
Slovak Republic & 0.4 & -1.3 & -5.2 & -5.0 & -3.6 & -12.3 & -6.0 & -5.7 & -3.7 \\
\hline Soln
\end{tabular}
Source: IMF.

\section{Capital Controls}

Of the EU8 countries, only Slovenia introduced major capital controls during the period. As was noted above, it seems that the Slovene URR was not effective in reducing total inflows; however, it was somewhat successful in changing the composition by discouraging shortterm inflows, and the introduction of custody accounts reduced portfolio inflows. The Czech Republic and Hungary also maintained the possibility of introducing controls (deposit requirements) in their foreign exchange laws, but never activated them. The prolonged process of capital account liberalization itself and the postponement of liberalization steps (such as for short-term transactions in Poland) were also responses to the inflows. The restrictions on financial derivatives and on lending to nonresidents in domestic currency, which were eliminated as some of the last steps taken in most countries, were especially important in reducing vulnerability in outflow episodes, such as the Russian crisis.

\section{Debt Management}

Some countries employed debt management in their policy tool sets to mitigate the effect of inflows. Hungary used part of its privatization receipts to repay debt to international financial institutions in the second half of the 1990s, and the Slovak Republic also repaid a large amount to the IMF before maturity. Poland established at the central bank a special account from privatization revenues to finance future debt service. This account was also used to fund buybacks of Brady bonds in 2000-02. Several countries shifted from external to domestic borrowing. For example, as a response to the heavy inflows, Hungary decided to renew all its maturing external and domestic debt in domestic currency in 2002. Poland and Slovenia also shifted to borrowing from the domestic market after 2000 and 2001, respectively. This step 
was also motivated by the desire to develop the domestic market for government securities and by other debt-management strategy considerations, such as risk management.

\section{E. Other Policy Responses}

Banking regulation and supervision continuously improved during the transition period in the EU8 countries, helping to monitor and reduce the risks related to heavy capital flows, but measures directly responding to capital flows were rare. One such measure was taken in Latvia, where large financial inflows through the banking system fueled credit growth to the private sector, prompting monetary authorities to tighten reserve requirements. The Czech Republic also introduced measures aimed at reducing short-term speculative inflows in 1995, including a limit on banks' net short-term liability positions to nonresidents and a limit for "short" short-term positions by banks to nonresidents. These measures were largely ineffective. ${ }^{35}$ In addition, in order to mitigate the effect of large FDI inflows and the anticipation of future inflows on the exchange rate, the bulk of the Czech Republic's foreign currency privatization receipts were converted directly at the central bank, thus circumventing the foreign exchange market. ${ }^{36}$ Large short-term inflows into Hungary through the banking sector in 2000 prompted monetary authorities to reduce reserves remuneration if a bank's on-balance-sheet open position exceeded 30 percent of its capital. In addition, the central bank used moral suasion and threats of stricter reserve requirements to stem the inflows. ${ }^{37}$

\section{Policy Implications For OTher Countries}

Successful transition economies have to learn to live with sizable capital inflows related to the real convergence process, but they should try to mitigate the size and volatility of the interest-rate-sensitive component of these inflows. In an environment of an increasingly open capital account, interest-rate-sensitive inflows will pose difficulties to monetary and exchange rate policy until the interest rate differential is greatly narrowed or eliminated. Given expectations for long-run exchange rate appreciation (the Balassa-Samuelson effect), the interest rate differential needs to be eliminated by lowering domestic nominal interest rates. Based on the experience of EU8 countries facing large capital flows, the following policy conclusions can be drawn for countries in similar circumstances:

Though monetary and exchange rate policies were the main policy tools for reacting to capital inflows in most EU8 countries, interest rate policy is much less effective in influencing domestic demand in emerging economies than in mature markets, and monetary

\footnotetext{
${ }^{35}$ See the IMF Independent Evaluation Office (2005).

${ }^{36}$ The government pays a fee that increases with the cumulative amount converted, in order to compensate the central bank for possible valuation losses on its increased foreign reserves. The funds converted are sterilized by the central bank through its repurchase operations.

${ }^{37}$ Wagner and Iakova (2001).
} 
and exchange rate policy independence is not as strong as it might seem. The interest rate transmission mechanism is weak, even in IT regimes, for some time due to the low indebtedness of the private sector, the easy availability of foreign exchange-denominated loans, high structural demand for borrowing, and the structural liquidity surplus in the financial system. ${ }^{38}$ Exchange pass-through is generally stronger in emerging economies than in mature economies, giving exchange rate policy special prominence. The exchange rate regime is important in influencing capital inflows, because it can alleviate or exacerbate discontinuities in the pricing of risk. ${ }^{39}$ Following the floating of the currency, prolonged periods of appreciation (or depreciation) have occurred all too often in other transition countries. It is very important that the authorities not contribute to one-way bets by implicit guarantees or hints at targeted levels.

Given the need to reduce domestic nominal interest rates and the uncertainties about the interest rate transmission mechanism, the speed of disinflation is key. If disinflation is slow, portfolio inflows will be persistent, given the prolonged period of sizable interest rate differentials, as Hungary and Poland discovered. This can lead to high credit growth and a large current account deficit. As the experience of the Czech Republic shows, if inflation comparable to levels in mature markets or only slightly above them can be achieved relatively quickly, interest-rate-sensitive inflows can decline greatly in the near or medium term. ${ }^{40}$ Thus, the policy mix should focus on relatively fast and sustainable disinflation, while aiming to minimize risks to the current account, financial stability, and economic growth. This is a difficult task and only feasible if the elements of the policy mix are highly coordinated and supportive of fast disinflation.

Since the effectiveness of monetary policy is limited and openness to global capital markets reduces the room to maneuver for monetary policy, fiscal and incomes policies should play a major role in managing demand. If disinflation is to be achieved quickly, fiscal and wage policy discipline is essential. Although several countries maintained generally prudent fiscal policies, fiscal tightening was rarely used as a direct response to inflows in EU8 countries, and this contributed to the slow pace of disinflation and widening current account deficits in some countries. Even in countries with significantly smaller budget deficit than that of EU8 countries, tightening of fiscal and wage policy is an important tool to reduce the emerging imbalances, as relying exclusively on a tighter monetary policy had limited effectiveness in managing demand. However, it is highly unlikely that a government can change the fiscal

\footnotetext{
${ }^{38}$ The interest rate transmission mechanism changes gradually, however, and monetary authorities are advised to conduct extensive research on the evolution of their monetary transmission mechanism.

${ }^{39}$ Lipschitz, Lane, and Mourmouras (2005).

${ }^{40}$ The Baltic countries have also received very modest amounts of interest-rate-sensitive inflows. Rapid disinflation played a limited part in this, the small size of domestic financial markets, thus the lack of domestic fixed-income securities to invest in, was a more important factor. Financial flows, however, have been persistent. These flows have been mostly motivated by gaining market share in retail banking, and not by the interest rate differential.
} 
stance in the magnitude and with the rapidity required to offset large shifts in the capital account.

The cautious approach to liberalizing the capital account seems to have served the more vulnerable EU8 countries well. As the example of Hungary and Poland shows, countries with slow disinflation and relatively large securities markets are especially advised to open up their capital accounts cautiously. As far as the effect of newly introduced capital controls is concerned, it is likely to be limited and temporary in an economy with large foreign ownership in the financial and enterprise sectors.

Finally, other policy measures in the areas of debt management and bank supervision and regulation can be useful additions to monetary and fiscal policy responses. Keeping privatization revenues off the interbank market (as in the Czech Republic), or repaying external debt early (as in Hungary and Poland) can alleviate the pressure on the exchange rate. In cases where financial inflows are large even in the absence of interest differentialsfor example, when motivated by gaining market share in retail banking-administrative measures may be the most effective policy tool. Bank regulation measures, such as tightening the reserve requirements on foreign liabilities (as in Latvia) can help reduce the large financial inflows which contribute to credit booms. 


\section{REFERENCES}

Arteta, C., B. Eichengreen, and C. Wyplosz, 2001, "When Does Capital Account Liberalization Help More Than It Hurts?” NBER Working Paper No. 8414 (Cambridge, Massachusetts: National Bureau of Economic Research).

Bakker A., and B. Chapple, eds., 2003, Capital Liberalization in Transition Countries: Lessons from the Past and for the Future (Cheltenham, England, and Northampton, Massachusetts: Edward Elgar).

Begg, D., and others, 2003, "Sustainable Regimes of Capital Movements in Accession Countries,” Policy Paper 10 (London: Centre for Economic Policy Research) available at http://www.cepr.org/pubs/books/PP10.asp.

Buch, C., 1999, “Capital Mobility and EU Enlargement,” K iel Working Paper No. 908 (Kiel, Germany: Institut für Weltwirtschaft an der Universität Kiel).

Buch C., and Hanschel E., 1999, “The Effectiveness of Capital Controls - The Case of Slovenia,” Kiel Working Paper No. 933 (Kiel, Germany: Institut für Weltwirtschaft an der Universität Kiel).

Buch C., R. Heinrich, and D. Piazolo, 1999, "Financial Flows to Transitional Economies in an Integrated Europe,” Economic Policy in Transitional Economies, Vol. 9 (no.2), pp. 89-122.

Buch C., and R. Heinrich, 2002, "Capital Flows to Transition Economies: How Risky Is Financial Integration?” ICEGEC Working Paper No.2 (Budapest, Hungary: International Center for Economic Growth European Center).

Buch, C., and L. Lusinyan, 2002, "Short-Term Capital, Economic Transformation and EU Accession,” Bundesbank Discussion Paper 02/02 (Frankfurt, Germany: Deutsche Bundesbank).

Buiter, W., and A. Taci., 2003, “Capital Account Liberalization and Financial Sector Development in Transition Countries," in Capital Liberalization in Transition Countries: Lessons from the Past and for the Future, ed. by A. Bakker, and B. Chapple, (Cheltenham, England, and Northampton, Massachusetts: Edward Elgar), pp. 105-41.

Caprirolo, G., and V. Lavrac, 2002, "Managing Capital Inflows in Slovenia: Experience and Options,” ICEGEC Working Papers No. 3 (Budapest, Hungary: International Center for Economic Growth European Center). 
Christensen, J., 2004, “Capital Inflows, Sterilization, and Commercial Bank Speculation: The Case of the Czech Republic in the Mid-1990s,” IMF Working Paper 04/218 (Washington: International Monetary Fund).

Cottarelli, C., G. Dell’Ariccia, and I. Vladkova-Hollar, 2003, “Early Birds and Sleeping Beauties: Bank Credit Growth to the Private Sector in Central and Eastern Europe and in the Balkans,” IMF Working Paper 03/123 (Washington: International Monetary Fund).

Edwards, S., 2001 “Capital Mobility and Economic Performance: Are Emerging Countries Different?” NBER Working Paper 8076 (Cambridge, Massachusetts: National Bureau of Economics Research).

Égert, B., 2004, “Assessing Equilibrium Exchange Rates in CEE Acceding Countries: Can We Have DEER with BEER without FEER?” William Davidson Institute Working Paper No. 664 (Ann Arbor, Michigan: University of Michigan).

IMF Independent Evaluation Office, 2005, “Report on the Evaluation of the IMF's Approach to Capital Account Liberalization,” (Washington: International Monetary Fund).

Ishii, S. and others, 2002, Capital Account Liberalization and Financial Sector Stability, IMF Occasional Paper No. 211 (Washington: International Monetary Fund).

Lipschitz, L., T. Lane, and A. Mourmouras, 2002, “Capital Flows to Transition Economies: Master or Servant?” IMF Working Paper 02/11 (Washington: International Monetary Fund).

, 2005, "Real Convergence, Capital Flows, and Monetary Policy: Notes on the European Transition Countries” In: Euro Adoption in Central and Eastern Europe: Opportunities and Challenges, ed. by S. Schadler (Washington, DC: International Monetary Fund).

Nord, R., 2003, “The Liberalization of the Capital Account in Hungary: Experiences and Lessons," in Capital Liberalization in Transition Countries: Lessons from the Past and for the Future, ed. by A. Bakker, and B. Chapple, (Cheltenham, England and Northampton, Massachusetts: Edward Elgar), pp. 195-208.

Rodrik, D., 1998, “Who Needs Capital Account Convertibility?” (unpublished; Cambridge, Massachusetts: John F. Kennedy School of Government), available at www.ksg.harvard.edu/rodrik.

Sadowska-Cieslak, E., 2003, “Capital Account Liberalization in Poland,” in Capital Liberalization in Transition Countries: Lessons from the Past and for the Future, ed. by A. Bakker, and B. Chapple, (Cheltenham, England and Northampton, Massachusetts: Edward Elgar), pp. 225-43. 
Schipke, A., and others, 2004, Capital Markets and Financial Intermediation in the Baltic States, IMF Occasional Paper No. 228 (Washington: International Monetary Fund).

Sutela, P., 2002, Managing Capital Flows in Estonia and Latvia. BOFIT Discussion Papers (Helsinki: Bank of Finland).

Thiel, E., 2003, "Recent Codes-Based Liberalization in the OECD“, in Capital Liberalization in Transition Countries: Lessons from the Past and for the Future, ed. by A. Bakker, and B. Chapple, (Cheltenham, England and Northampton, Massachusetts: Edward Elgar), pp. 85-104.

Wagner, N., and D. Iakova, 2001, "Financial Sector Evolution in the Central European Economies: Challenges in Supporting Macroeconomic Stability and Sustainable Growth,” IMF Working Paper 01/141 (Washington: International Monetary Fund). 
Figure A1. Selected EU8 Countries: Public Debt (As a percent of GDP)

Czech Republic, 1993-2004

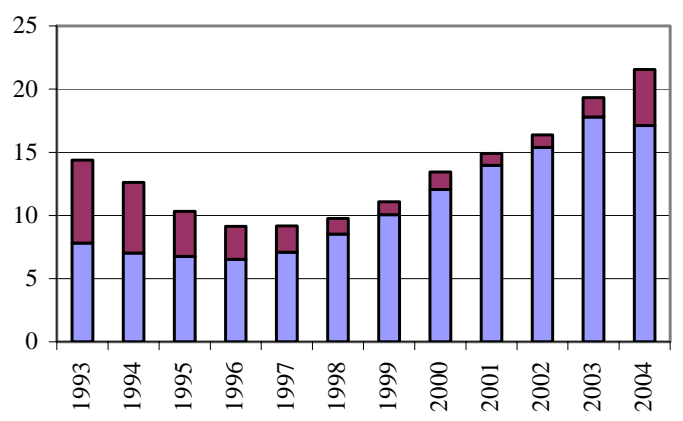

Lithuania, 1993-2003

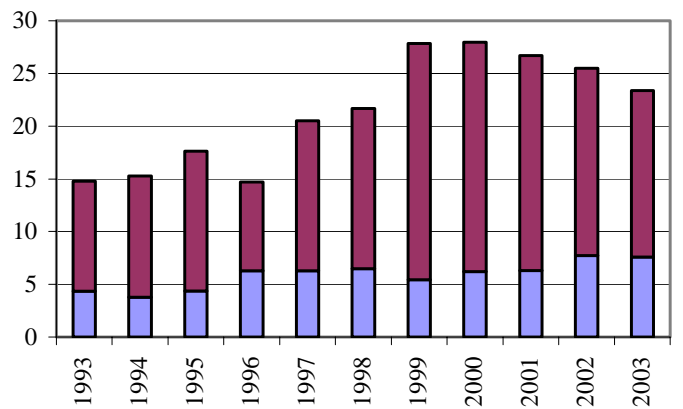

Slovak Republic, 1996-2003

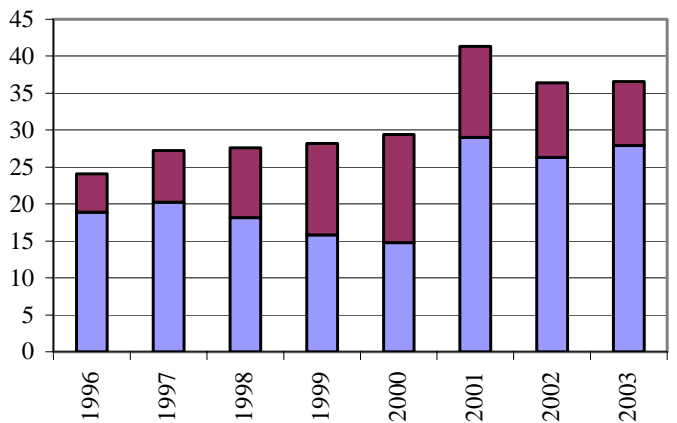

$\square$ Domestic debt 口Foreign debt

Source: IMF, IFS.
Hungary, 1993-2004

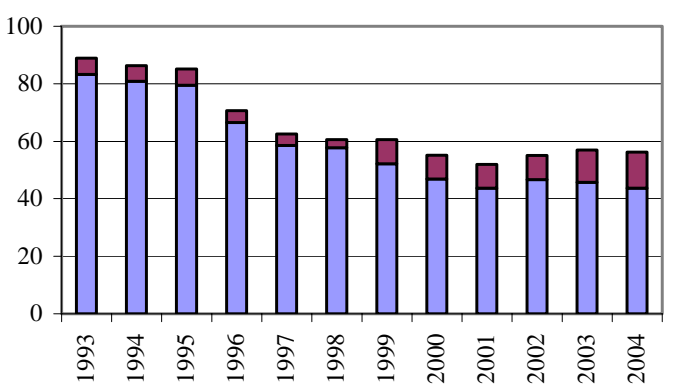

Poland, 1994-2001

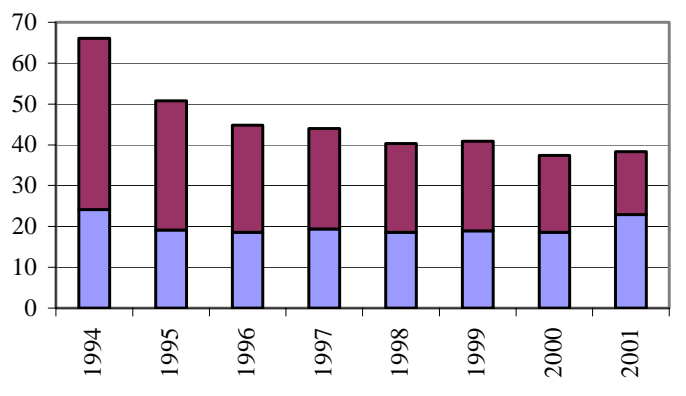


Figure A2. EU8 Countries: End-of-Period CPI Inflation, 1995-2004 (In percent)

\section{Czech Republic}

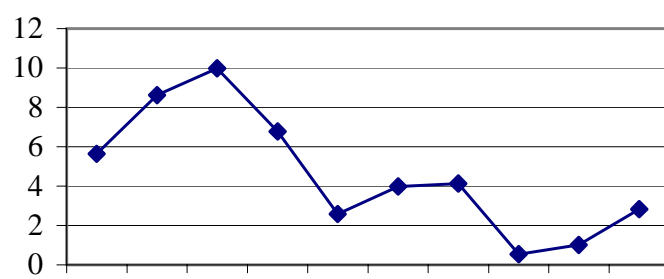

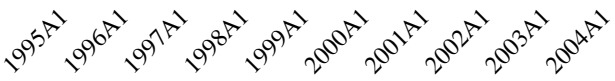

Hungary

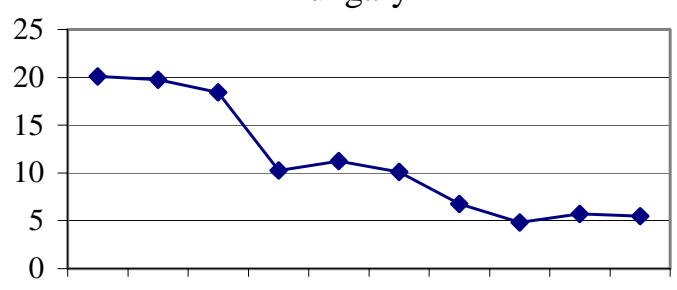

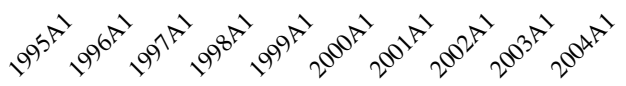

Lithuania

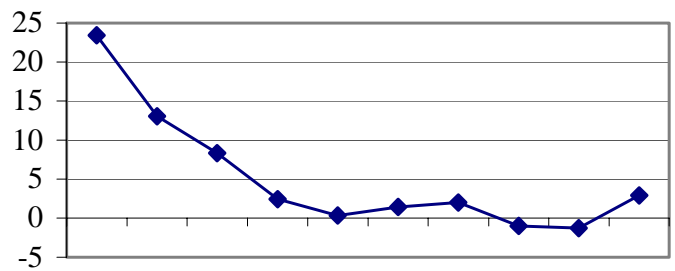

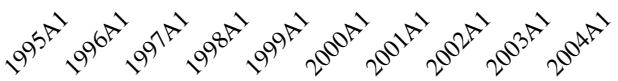

Slovak Republic

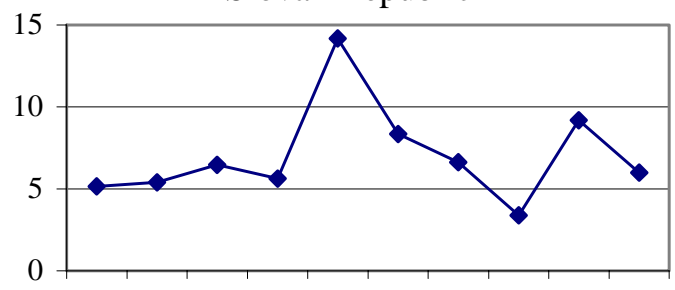

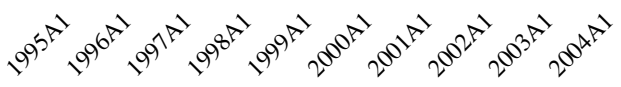

Source: IMF, IFS .

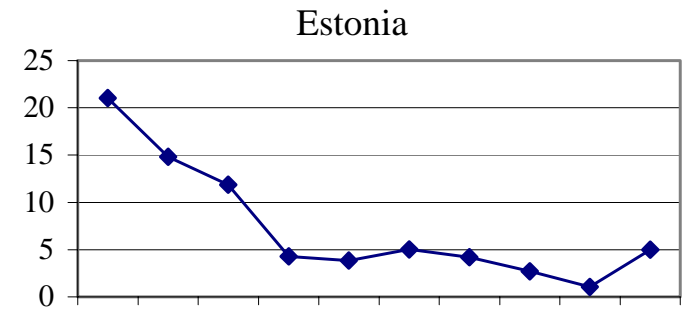

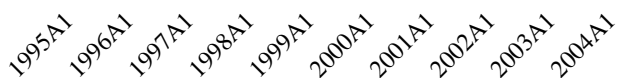

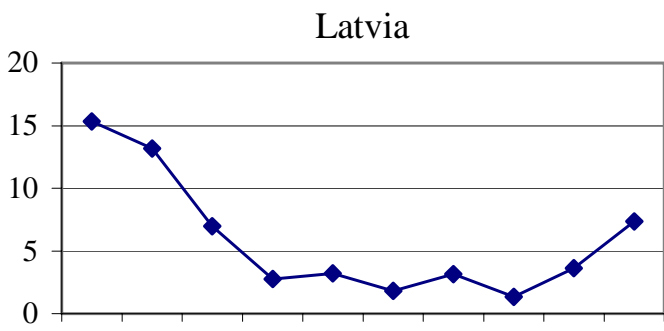

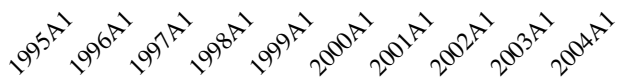

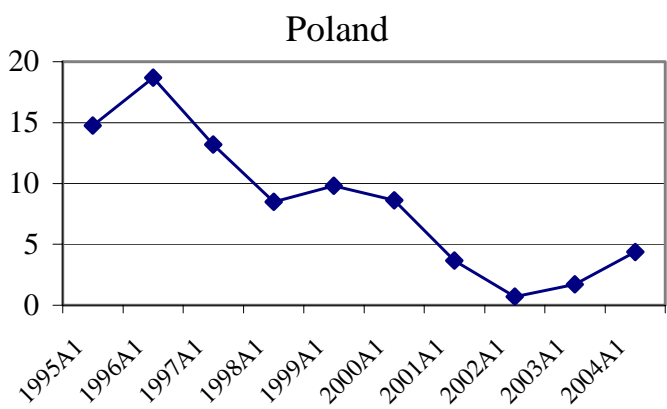

Slovenia

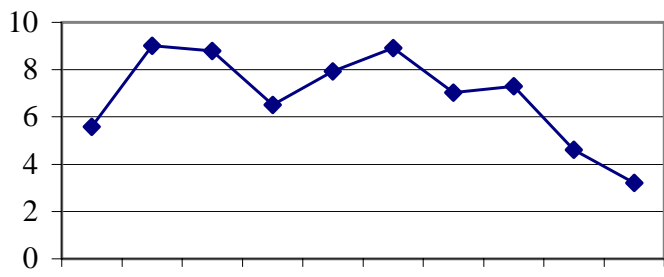

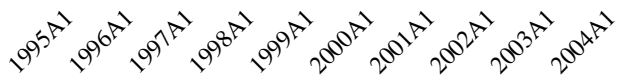


Figure A3. Selected EU8 Countries: Monetary Policy and Exchange Rate Reactions

Czech Republic, 1997-2004

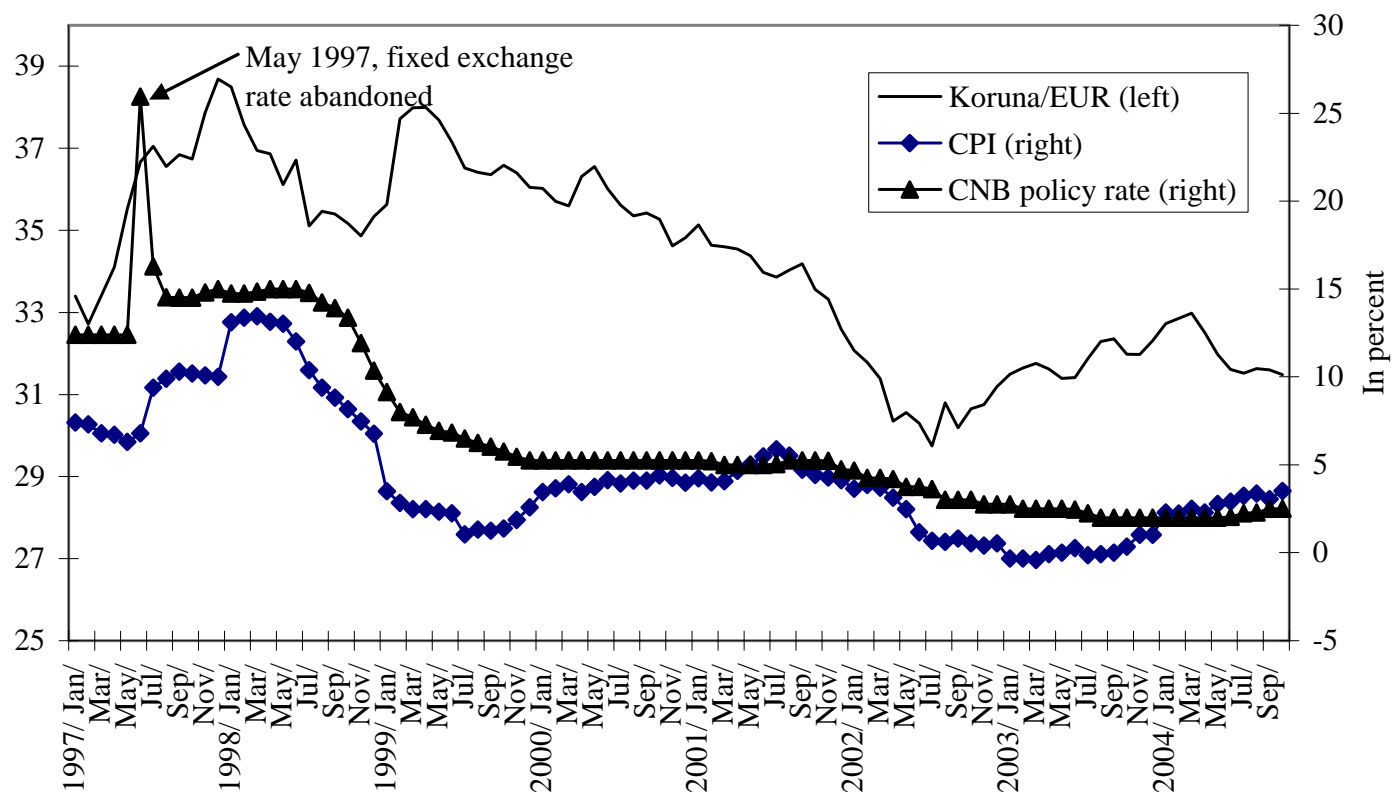

Hungary, 1999-2004

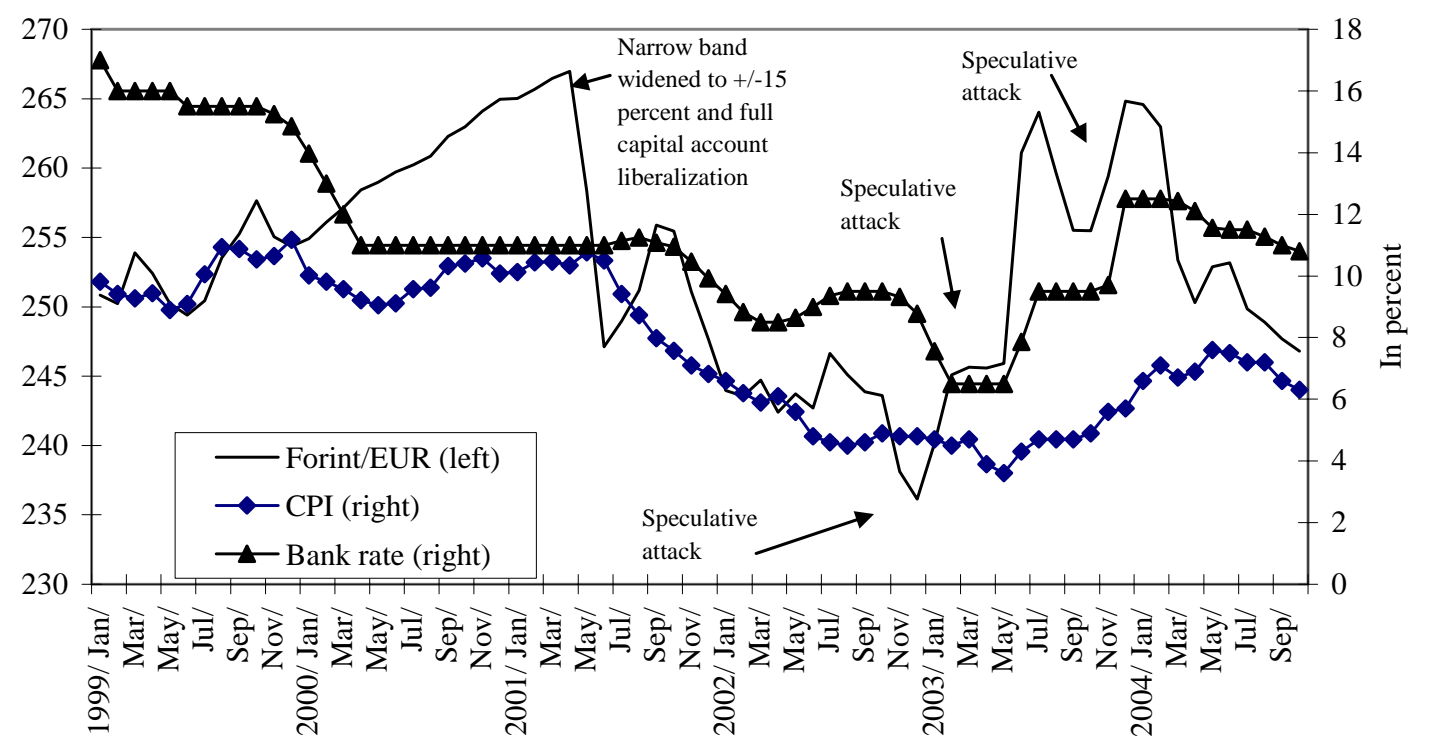


Figure A3. Selected EU8 Countries: Monetary Policy and Exchange Rate Reactions (continued)

Poland, 1999-2004

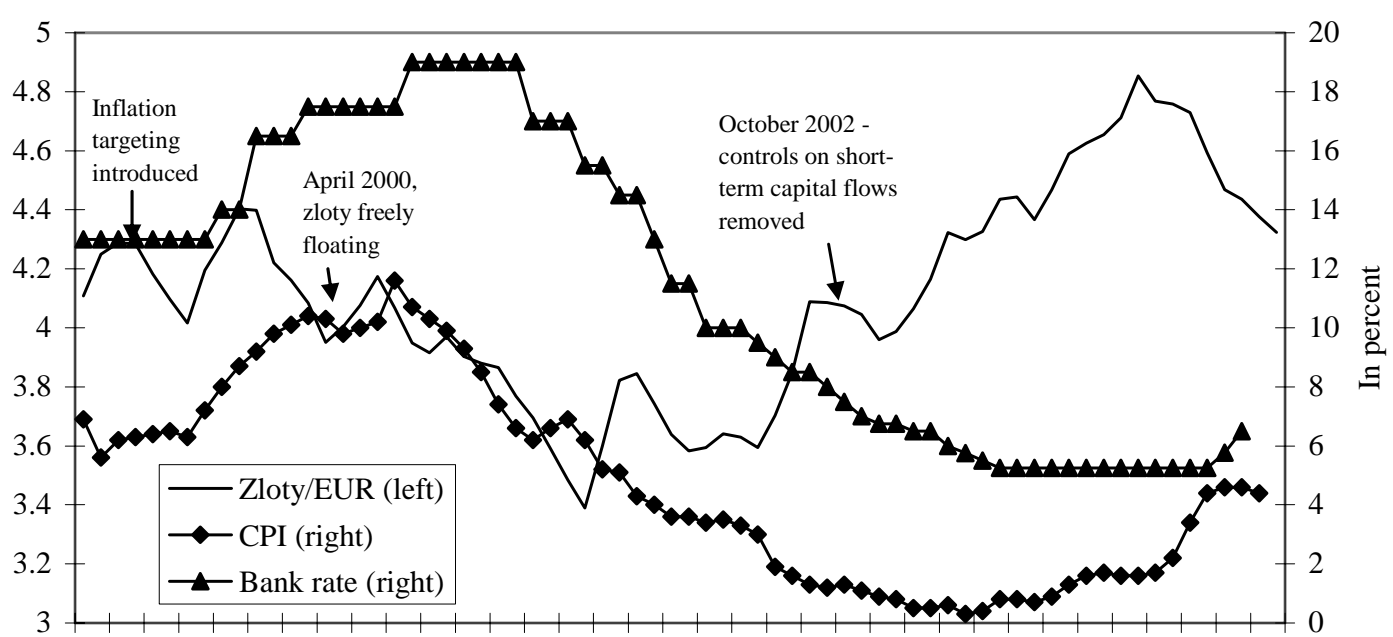

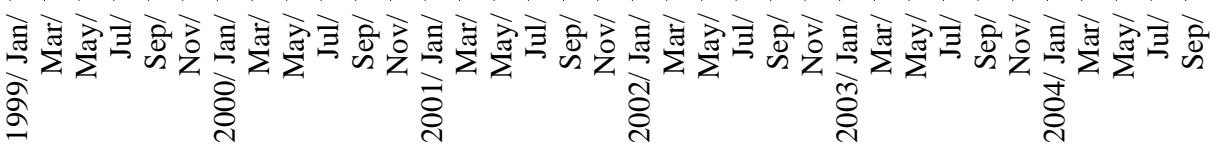

Slovenia, 1999-2004

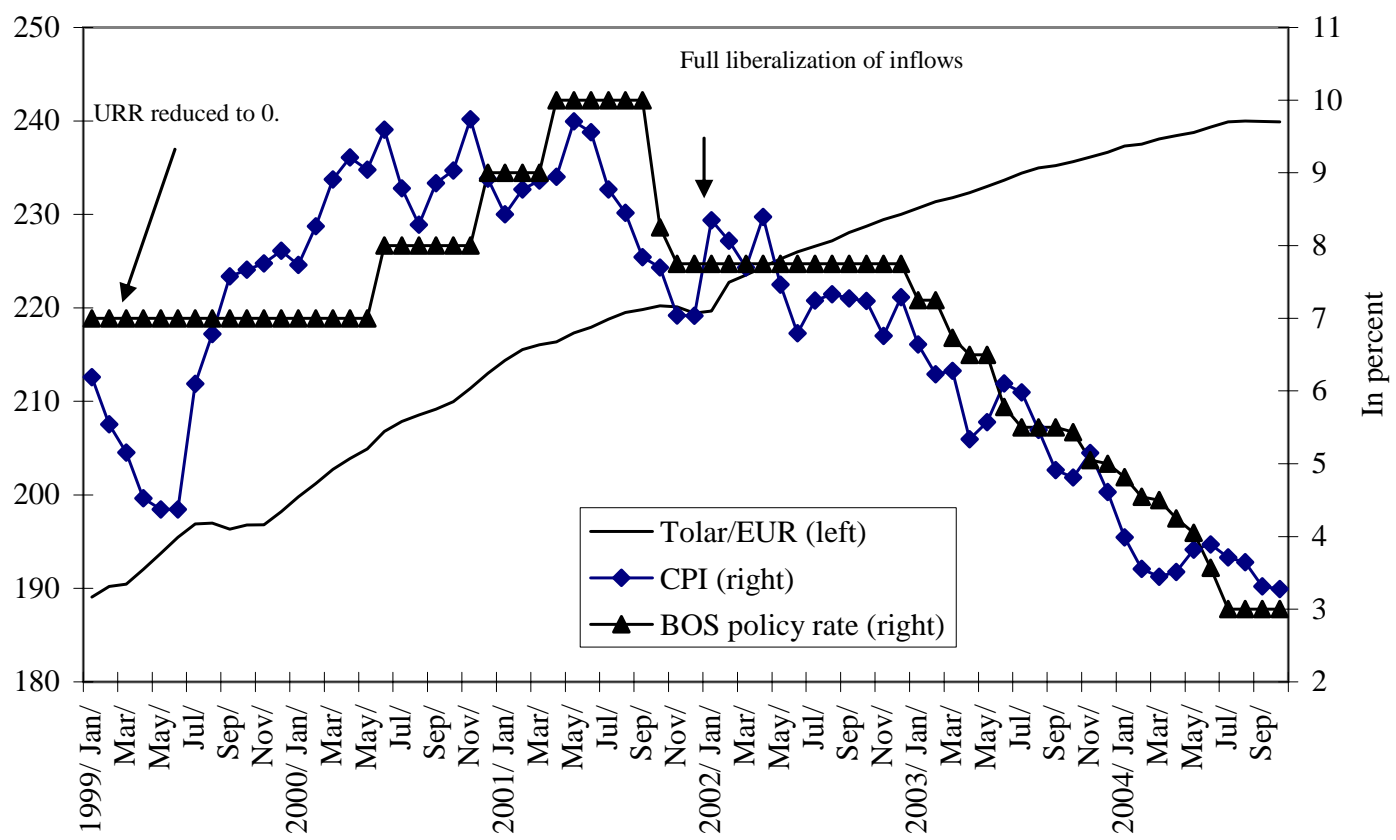


Figure A3. Selected EU8 Countries: Monetary Policy and Exchange Rate Reactions (concluded)

Slovak Republic

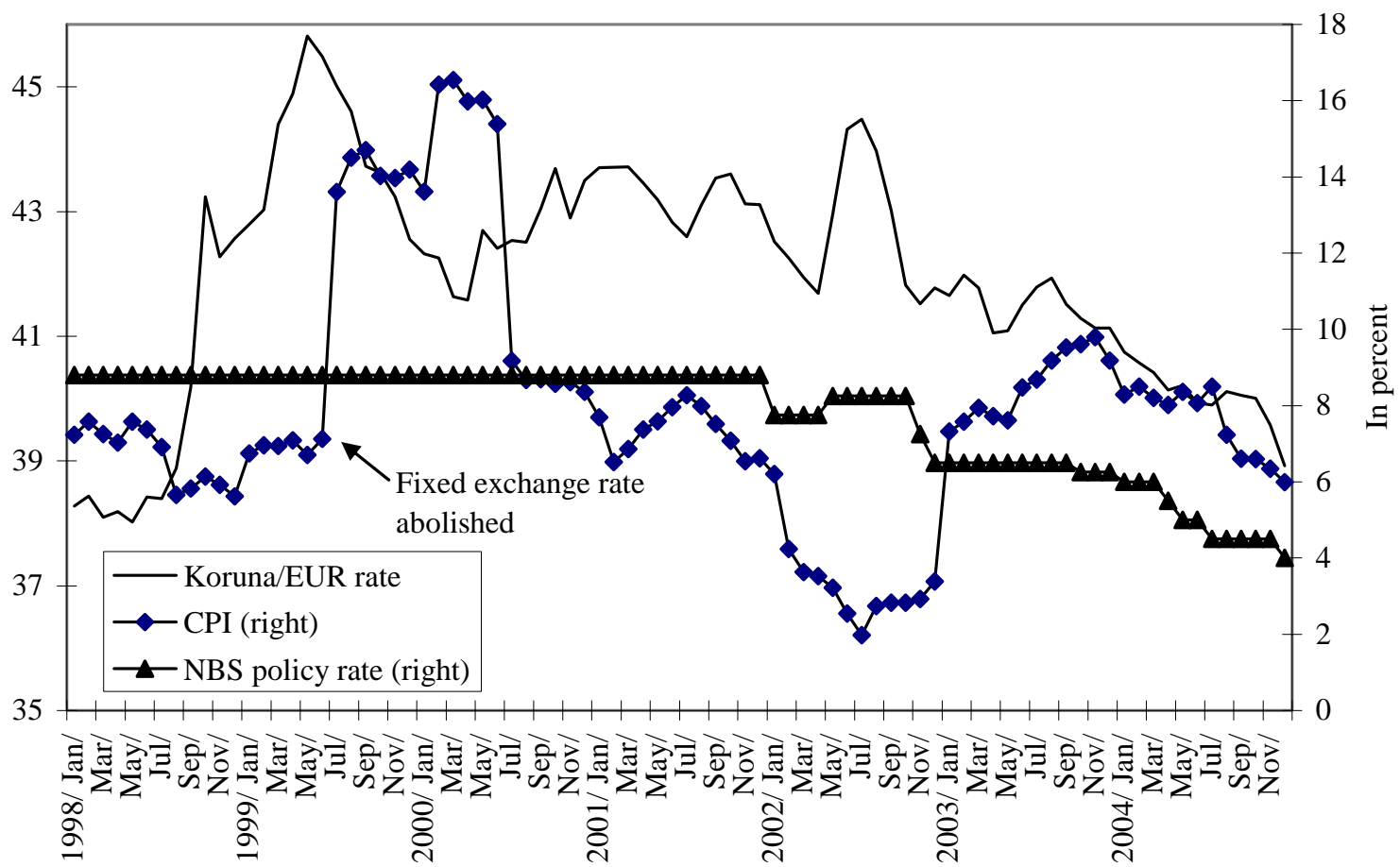

Sources: IMF, IFS; and national central banks.

Table A1. Selected EU8 Countries: Nonresident Holdings of Government Securities, 1997-2004

(End of period; percent of total stock)

\begin{tabular}{|c|c|c|c|c|c|c|c|c|c|}
\hline & & & 1998 & 1999 & 2000 & 2001 & 2002 & 2003 & 2004 \\
\hline Czech Republic & & 8.7 & $\ldots$ & ... & $\ldots$ & $\ldots$ & $\ldots$ & 5.4 & 17.6 \\
\hline Hungary & & 2.8 & 8.6 & 11.2 & 16.8 & 20.6 & 27.2 & 27.4 & 28.6 \\
\hline Latvia & ... & & $\ldots$ & $\ldots$ & 2.8 & 9.2 & 1.9 & 4.2 & 4.2 \\
\hline Lithuania & & 1.2 & 1.4 & 4.7 & 6.7 & 3.7 & 3.7 & 5.5 & 7.5 \\
\hline Poland & ... & & ... & 7.4 & 15.1 & 13.1 & 16.7 & 17.8 & 22.2 \\
\hline Slovak Republic 1/ & $\ldots$ & & $\ldots$ & $\ldots$ & 10.0 & 8.0 & 8.3 & 12.4 & 19.4 \\
\hline
\end{tabular}

Sources: National central banks and ministries of finance.

Notes: No data available for Slovenia. Estonia not reported due to its very small stock of government securities throughout the period.

1/: Ownership of government bonds only. 
Table A2. EU8 Countries: Real GDP Growth and the Current Account Balance, 1995-2003 (GDP growth in percent and current account balance as a percent of GDP)

\begin{tabular}{lllllllll}
1995 & 1996 & 1997 & 1998 & 1999 & 2000 & 2001 & 2002 & 2003 \\
\hline
\end{tabular}

\section{Czech Republic}

$\begin{array}{llllllllll}\text { Real GDP growth } & 6.4 & 4.8 & -1.0 & -2.2 & -0.8 & 3.1 & 2.6 & 1.5 & 3.1\end{array}$

$\begin{array}{llllllllll}\text { Current account balance } & -2.7 & -7.4 & -6.1 & -2.4 & -3.0 & -4.8 & -5.4 & -5.6 & -6.2\end{array}$

\section{Estonia}

$\begin{array}{llllllllll}\text { Real GDP growth } & 4.3 & 3.9 & 10.6 & 4.7 & -0.1 & 7.8 & 6.4 & 7.2 & 5.1\end{array}$

$\begin{array}{llllllllll}\text { Current account balance } & -4.4 & -9.2 & -12.2 & -9.2 & -4.4 & -5.5 & -5.6 & -10.2 & -13.2\end{array}$

\section{Hungary}

$\begin{array}{llllllllll}\text { Real GDP growth } & 1.5 & 1.3 & 4.6 & 4.9 & 4.2 & 5.2 & 3.8 & 3.3 & 2.9\end{array}$

$\begin{array}{llllllllll}\text { Current account balance } & -5.6 & -3.7 & -2.1 & -4.9 & -7.9 & -8.7 & -6.2 & -7.2 & -8.9\end{array}$

\section{Latvia}

$\begin{array}{llllllllll}\text { Real GDP growth } & -0.8 & 3.3 & 8.6 & 3.9 & 1.1 & 6.6 & 8.0 & 6.4 & 7.5\end{array}$

$\begin{array}{llllllllll}\text { Current account balance } & -0.4 & -4.6 & -5.1 & -9.8 & -9.8 & -6.4 & -8.9 & -6.5 & -8.6\end{array}$

\section{Lithuania}

$\begin{array}{llllllllll}\text { Real GDP growth } & 3.3 & 4.7 & 7.3 & 5.1 & -3.9 & 3.9 & 6.4 & 6.8 & 9.7\end{array}$

$\begin{array}{llllllllll}\text { Current account balance } & -10.2 & -9.1 & -10.3 & -12.1 & -11.2 & -6.0 & -4.7 & -5.2 & -7.0\end{array}$

\section{Poland}

$\begin{array}{llllllllll}\text { Real GDP growth } & 7.0 & 6.0 & 6.8 & 4.8 & 4.1 & 4.0 & 1.0 & 1.4 & 3.8\end{array}$

$\begin{array}{llllllllll}\text { Current account balance } & 4.2 & -1.0 & -3.0 & -4.3 & -7.5 & -6.0 & -2.9 & -2.6 & -1.9\end{array}$

\section{Slovak Republic}

Real GDP growth

$\begin{array}{rrrrrrrrr}6.9 & 6.6 & 6.5 & 4.4 & 1.9 & 2.0 & 3.8 & 4.6 & 4.5\end{array}$

Current account balance

$\begin{array}{lllllllll}2.2 & -11.2 & -10.1 & -10.4 & -5.7 & -3.5 & -8.4 & -8.0 & -0.9\end{array}$

\section{Slovenia}

Real GDP growth

$\begin{array}{rrrrrrrrr}4.1 & 3.5 & 4.6 & 3.8 & 5.9 & 4.1 & 2.9 & 2.9 & 2.3\end{array}$

Current account balance

$\begin{array}{llll}-0.5 & 0.2 & 0.1 & -0.8\end{array}$

\begin{tabular}{lllll}
-3.3 & -2.8 & 0.2 & 1.4 & 0.1 \\
\hline
\end{tabular}

